\title{
A Momentary Lapse of Reason? Assessing the Pre- and Post-Brexit Preferences of UK Citizens
}

\author{
Etienne Farvaque ${ }^{1+}$, Muhammad Azmat Hayat ${ }^{2}$ and Ifrah Siddique ${ }^{2}$ \\ ${ }^{1}$ University of Lille, France \\ ${ }^{2}$ University of the Punjab, Pakistan
}

\begin{abstract}
We analyze the persistence of the major determinants of distrust toward the European Union (EU) and pro-Brexit voting attitudes of citizens of the United Kingdom. Looking both backward and forward, our analysis confirms that Euroscepticism is deep-rooted, although the data reveal differences across different parts of the country. We observe no major transformation in the favor of the EU over the last two decades or in the post-referendum period. We also carry out an age-period-cohort analysis by interacting age and cohort effects with time to analyze the evolution of individual preferences. We find that an aging population will promote Eurosceptic assertiveness. We then implement a demographic forecasting analysis to predict whether the level of distrust of older cohorts can be offset by differing attitudes among younger cohorts in the future. On the contrary, we find that demographic trends will tend to strengthen distrust in the EU.
\end{abstract}

Keywords: Brexit, voting, attitudes, preferences, distrust, European Union

\section{Introduction}

Since the referendum on Brexit organized in the United Kingdom (UK), the country has undergone many political upheavals, the pound has lost value, and the negative economic consequences of Brexit seem to be looming as the country's exit from the European Union (EU) approaches. ${ }^{1)}$ Even if Leave voters have experienced a higher level of life satisfaction after the vote (Powdthavee et al., 2019), the population seems to acknowledge that Brexit will not improve the country's prospects. The survey data (from the British Election Study) shown in Table 1 reveal that expectations for an auspicious future along numerous dimensions, from

+Corresponding Author: Etienne Farvaque

Professor, University of Lille, CNRS, IESEG School of Management, UMR 9221 - LEM - Lille Économie Management, F-59000 Lille, France, and CIRANO, Montréal, Québec, Canada. Email: etienne.farvaque@univ-lille.fr

Co-Author: Muhammad Azmat Hayat

Associate Professor, Department of Econometrics and Quantitative Methods, School of Economics, University of the

Punjab, Lahore, Pakistan. Email: azmathayat.eco@pu.edu.pk

Co-Author: Ifrah Siddique

M.Phil. Student, Department of Economics, University of the Punjab, Lahore, Pakistan.

Email: ifrah.siddique890@gmail.com 
the National Health System (NHS) to the respondents' own situations, are increasingly less prevalent among British people. In parallel, since the end of the Brexit campaign, the Remain option has been increasingly favored by respondents, whereas preferences for the alternative Leave option have fallen, albeit by a small margin (see Figure 1).

This finding leads us to wonder whether the decision to leave would be repeated. In other words, we ask whether the results of the vote would be the same if a second referendum were held today. They likely would be the same if the underlying determinants that led to this drastic and even historical decision are deeply rooted.

The literature shows the importance of going beyond aggregate data to highlight the individual and regional determinants of the preferences that led to the Brexit decision (Alabrese et al., 2019; Becker et al., 2017; Curtice, 2017; Los et al., 2017). Although financial issues have been shown to be important (Arnorsson \& Zoega, 2018; Fidrmuc et al., 2019; Liberini et al., 2019), demographic trends may also have played a role (Eichengreen et al., 2021).2)

We contribute to this literature by considering both historical (starting in 1997) and current (i.e., the post-Brexit period) data. Hence, this study differs from existing studies in that it evaluates the historical evolution of the characteristics explaining people's distrust in the EU and considers at their potential evolution in the future. Concretely, this study compares the British Election Study with feelings about the EU since 1997 to estimate the evolution of the Leave vote since the relevant data were first recorded. We therefore compare the results on distrust and on preferences for Brexit to verify whether the types of individuals who distrusted the EU the most were the same types of individuals who tended to vote for Brexit.

We use detailed individual-level survey data from both the British Election Study and the Eurobarometer Survey to better understand the persistence of pro-Brexit preferences. We use the first dataset to directly evaluate whether the determinants of the decision to vote for the Leave option still dominate, whereas we use the second type of data to assess the same question with regard to distrust in the EU. We compare pre- and post-Brexit data to analyze whether the determinants of Brexit have evolved. In the spirit of Eichengreen et al. (2021), we also estimate an age-period-cohort (APC) model using our data to identify whether the effect of distrust toward the EU is likely to disappear over time or persist. Finally, we also investigate these issues at the regional level to assess whether any regional patterns emerge and determine how these trends may change over time given the existing demographic projections.

We obtain the following results. First, the analysis reveals that the demographic characteristics related to feelings of distrust toward the EU (i.e., age, education, occupation, and political ideology) are also related to Leave votes on the Brexit referendum. Second, we observe no major shift in stated preferences before and after the referendum, meaning that the post-referendum economic

1) For a description and quantification of the consequences of Brexit, see, for example, Bisciari (2019), Hall and Henry (2019), and Latorre et al. (2019).

2) See Campos (2019) for a survey of the literature on the determinants and consequences of Brexit. 
concerns about the consequences of Brexit (as Table 1 shows) have failed to change the survey respondents' Eurosceptic mood thus far. Third, the APC analysis shows that people belonging to older cohorts are more skeptical toward the EU than members of more recent birth cohorts are. It also shows that people become more pessimistic about the EU as they age. Fourth, the regional APC analysis reveals that age and cohort effects are less prevalent in Scotland, Wales, and London, confirming the electoral divide in the UK.

In sum, the age effect reveals that distrust in the EU is increasing over time, whereas the cohort effect shows that it is decreasing over time. If these trends are a guide, then older people's degree of distrust should be replaced by the more trustful feelings of younger cohorts in the future. However, we show that population projections do not support this argument; as the age structure shifts, the share of older people in the UK will increase, meaning that the cohort effect cannot offset the age effect over the coming generations. The age factor will therefore become even more dominant, confirming the UK's status as a Eurosceptic nation.

The remainder of this paper is structured as follows. The next section reviews the literature, and Section 3 details the data and methodology upon which we build the first part of the analysis, which looks at the determinants of distrust and Leave votes. This analysis is described in Section 4. Section 5 provides the results of the APC analysis that we run for the national and regional levels and shows whether demographic projections will dampen or reinforce the strong age effects that we identify. Section 6 concludes.

Table 1. Consequences of Brexit: Evolution of Opinions

\begin{tabular}{|c|c|c|}
\hline Expected outcome after leaving the $E U$ & 2016 (\% of total) & 2019 (\% of total) \\
\hline \multicolumn{3}{|l|}{ Effect on the NHS after leaving the EU } \\
\hline Worse & 23.27 & 38.75 \\
\hline About the same level & 41.08 & 37.32 \\
\hline Better & 35.16 & 20.24 \\
\hline \multicolumn{3}{|c|}{ Effect on unemployment after leaving the EU } \\
\hline Lower & 24.22 & 17.45 \\
\hline About the same level & 43.91 & 44.68 \\
\hline Higher & 31.86 & 37.86 \\
\hline \multicolumn{3}{|l|}{ Effect on the economy after leaving the $E U$} \\
\hline Worse & 40.19 & 49.66 \\
\hline About the same level & 34.12 & 29.33 \\
\hline Better & 25.68 & 20.99 \\
\hline \multicolumn{3}{|l|}{ Effect of immigration on economy } \\
\hline Bad & 27.45 & 13.95 \\
\hline Good & 20.88 & 35.71 \\
\hline \multicolumn{3}{|c|}{ Effect of leaving the $E U$ on my personal financial situation } \\
\hline Worse & 23.30 & 30.23 \\
\hline Better & 9.00 & 6.88 \\
\hline
\end{tabular}

(Source) Authors' calculations based on waves 8 and 15 of the British Election Study. 
Figure 1. Evolution of the leave vote

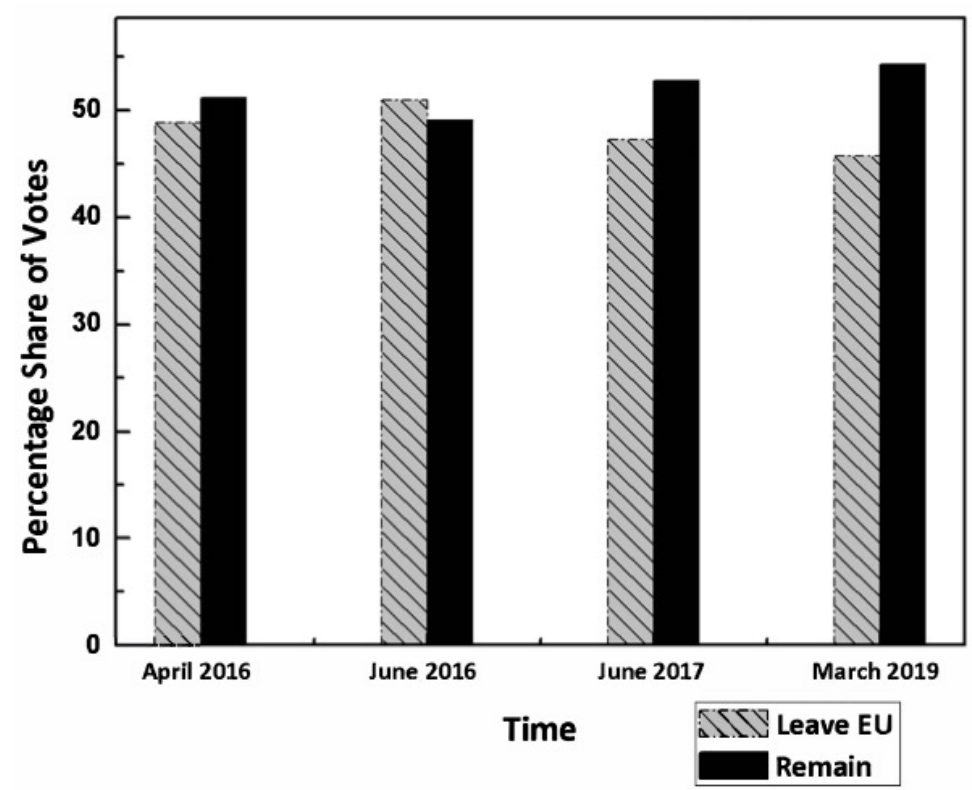

\section{Literature Review}

\section{A. Euroscepticism in the UK}

Britain is well known for its strong tradition of Euroscepticism, and this phenomenon has caught researchers' attention. Euroscepticism's roots can be traced back to at least Margaret Thatcher's agenda, and it now has a prevalent influence over political parties in the UK (AlexandreCollier, 2015; Hertner \& Keith, 2017). The persistence of British Euroscepticism can be approached from two main theoretical perspectives.

The first approach relates economic opportunity to attitudes toward European integration, with a lack of opportunity leading to anger and blame toward the EU. From this perspective, individual support for the EU is based on a cost-benefit analysis whereby people who can reap larger benefits from the EU are more likely to support it (Anderson \& Reichert, 1995; Clements, 2011; Gabel, 1998; Gabel \& Palmer, 1995; Garry \& Tilley, 2014; McLaren, 2007). This finding means that people who are more educated, financially better-off, or hold good jobs are more likely to support the EU than people who are less educated or earn lower wages are. Consequently, Eichengreen et al. (2021) predict that recent cohorts should be less Eurosceptic the earlier cohorts are, with their relatively more pro-European attitudes reflecting their higher levels of education. 
Empirical studies investigating the characteristics of individuals who voted to leave the EU also suggest that older, less educated voters and lower-income voters live in places with lower levels of gross domestic product per capita. Respondents who identify themselves as belonging to a working-class family, being rather religious, and coming from a white ethnic background are more likely to vote in favor of Brexit (Arnorsson \& Zoega, 2018; Becker et al., 2017; Hobolt, 2016; Liberini et al., 2019).

Becker et al. (2017) show that the probability of voting in favor of Brexit is higher among individuals in regions characterized by higher levels of unemployment, lower income levels, and a historical reliance on the manufacturing sector. Lee et al. (2018) also suggest that residential immobility is an important driver of the Brexit vote. People who live in the place where they were born are more likely to vote for Brexit, particularly if these places are facing economic slumps. Menon et al. (2019) conduct analyses showing that disparities in attitudes toward the EU across different parts of the UK have grown even larger (in particular, Scotland is torn between its own independence and staying in a post-Brexit union with England, whereas Wales can be seen as representing the aggregate view of UK citizens). Moreover, Fetzer and Wang (2020) reveal that the economic divergence across regions induced by the Brexit vote is already exacerbating the regional economic inequalities reflected in the 2016 Brexit referendum vote patterns.

The second theoretical approach to the persistence of British Euroscepticism accounts for xenophobic attitudes. These attitudes consider immigration to be a threat to British culture and national identity because it promotes cosmopolitanism. Thus, individuals who are sensitive about their exclusive national and cultural identities are more likely to oppose the EU (Brigevich, 2016; Carey, 2002; Elgün \& Tillman, 2007; Hooghe \& Marks, 2005; Kuhn \& Stoeckel, 2014; Luedtke, 2005). Most studies conclude that immigration issues lie at the core of the results of the Brexit referendum (O'Reilly et al., 2016). Again, the source of the vote can be traced back in time to the Commonwealth Immigration Act of 1962, which aimed to restrict immigration from Commonwealth countries (Menon et al., 2019).

Although the effect of distance from immigrants on electoral attitudes remains debatable (David et al., 2018), Jolly and DiGiusto (2014) show that large immigrant populations tend to fuel xenophobic attitudes. Carey (2002) suggests that a higher association with one's country and a strong feeling of national identity decreases support for the EU. Kuhn and Stoeckel (2014) indicate that in the aftermath of the global financial crisis, the EU is seen as creating a greater threat to countries' national identities. They find that this feeling is particularly strong in richer countries. In this context, studies show that individuals who believe that a higher level of immigration undermines the national culture and threatens the welfare state are more likely to vote in favor of Brexit (Arnorsson \& Zoega, 2018; Goodwin \& Milazzo, 2017; Hobolt, 2016). By this reasoning, immigrants are viewed not only as a threat to British culture but also as a burden on the economy (Clery et al., 2016), with a prevalent fear that a greater 
influx of people, particularly from some relatively poor European countries, may eliminate jobs for British nationals. Menon et al. (2019) emphasize that an estimated $61 \%$ of Leave voters believe that immigration has increased unemployment among less skilled workers, $53 \%$ of them think that immigrants decrease the quality of health care services, and $75 \%$ of them believe that immigrants have increased the crime rate.

These two approaches highlight the determinants of the persistence of anti-EU feelings and attitudes in Britain. They also highlight an indelible division within British public opinion regarding the European integration process. However, a question remains as to whether these economic and demographic determinants of attitudes are deeply rooted and, thus, will drive the UK's preferences in the future or if a reversal can be expected. This study intends to answer this question.

\section{B. Age and conservatism}

Since at least Glenn (1974), the relation between age and conservatism has been debated. This relation can be obscured by the fact that preferences become more entrenched with age and move more slowly, if at all. From this perspective, conservatism therefore simply means that people tend to change less over time. Theoretical explanations for the relation between age and conservatism are provided from psychological, social, economic, and physiological perspectives. Peterson et al. (2020) offer a survey of the theoretical literature.

Empirically, Danigelis and Cutler (1991) analyze race relations and find no evidence of different behaviors across generations. Danigelis et al. (2007) confirm this result and also provide evidence on attitudes related to civil liberties and privacy issues. These findings may arise because the age-conservatism perspective tends to obscure the fact that people of a cohort share common interests that may trump their own individual preferences, as Rhodebeck (1993) shows. Haselswerdt's (2020) results tend to support this interpretation; he looks at people's thoughts about policy changes conditional on the fact that they will gain or lose from the changes and finds that selfinterest considerations matter. He finds that older people have a greater tendency to hold the same opinion than younger generations do. de Mello et al. (2017) obtain similar results and discuss the "grey peril" effect in the context of preferences for different types of public expenditures. Peterson et al. (2020) reach stronger conclusions, finding that if political attitudes are indeed stable over the life cycle, the variations come from liberals shifting to more conservative views and not the opposite.

The latter studies use long-term surveys from the US to establish their arguments and aim to disentangle age and cohort effects. Because being 40 years old may not mean the same thing in 1990 and 2010, ages and birth cohorts must be differentiated. The APC model offers a way to disentangle these two characteristics. For example, Fullerton and Dixon (2010) use this model to revealing different preferences on social security across cohorts and people who are close 
to retirement (age), whereas Schwadel and Garneau (2014) use the model to identify cohortrelated changes in preferences for tolerance (with regard to, for example, sexual orientation). Sørensen (2013) also uses an APC model to analyze preferences for public services and reveals that life-cycle changes in preferences may be small but that the effects vary strongly across countries.

In the context of political attitudes and voting, however, the APC model reveals a strong relationship between age and conservatism in Britain (Tilley \& Evans, 2014). Moreover, Tilley and Evans (2014) show that aging substantially increases the likelihood of voting for the Conservative party. They also show that newer generations are not trending toward lower rates of voting for the Conservative party. Grasso et al. (2017) confirm this result, finding strong cohort effects on right-authoritarian values. They associate these effects with the generation that were raised under Thatcher, but they find no discontinuity after this generation (for the subsequent "Blair's Babies" generation in particular). If Brexit is associated with positions defended by Conservatives, then this effect should also appear in the context of Brexit, and the question is worth exploring.

\section{Pre-Brexit Determinants: Data and Methodology}

To compare historical feelings with the Brexit referendum results, we use data from Eurobarometer and the British Election Study to check whether the determinants of distrust with regard to the EU are the same as those of the pro-Brexit vote.

Eurobarometer surveys investigate a wide variety of public opinions on general European issues in depth throughout the EU's member states. Here, we focus on Great Britain (i.e., England, Wales, and Scotland). Eurobarometer surveys have been conducted on the behalf of the European Commission since 1973, and the results are published and maintained on the Gesis website. ${ }^{3}$ ) We use all waves of the Eurobarometer from 1997 (wave 48.0) to April 2019 (wave 91.5) that include a question about trust in the EU (see Appendix Table A1).

A typical expression of the question about trust in the EU is that of "QA8a" in Eurobarometer 85.2, conducted in May 2016:

"QA8a for each of you, do you tend to trust following institutions or tend not to trust? QA8a-9 European Union"

Respondents' answers are recorded as one for "tend to trust," two for "tend not to trust," and three for "don't know." We convert this categorical variable into a binary variable by defining one as "distrust" and zero as "trust" and excluding the third category. This binary variable (i.e., distrust in the EU) is our first dependent variable.

3) https://www.gesis.org/home. 
For the Brexit referendum, data are taken from waves 7, 8, 13, and 15 of the British Election Study, as a question about Brexit was first asked in May 2016 (wave 7) and has been reintroduced in the most recent survey waves (see Appendix Table A2).4) The question about the Brexit referendum is worded as:

"How would you vote in Brexit referendum?"

Respondents' answers are recorded as one for "Leave the EU," zero for "Stay in EU," and three for "I will not vote." This categorical variable is converted into a binary variable as one for "Leave the EU" and zero for "Stay in EU," and we exclude the third category. This binary variable on the Leave vote is our second dependent variable.

Because our dependent variables for both distrust in the EU and the Brexit vote are dichotomous, a survey-based logit regression is best suited for our analysis. Removing the third categories (i.e., "don't know" and "I will not vote," respectively) for both dependent variables leads to sample selection bias. Even though few respondents give these responses, this bias must be addressed, if only because the opinions of respondents in these categories may change over time (crisis periods, for example, can lead to more expressive behaviors). Hence, we conduct a Heckman test to calculate the average margins including the "don't know" categories.

A linear regression is inappropriate for predicting probabilities in the case of binary outcomes for both conceptual and statistical reasons. An adequate methodology is the binary logit regression (e.g., Çokluk, 2010). A logit model is a non-linear transformation of a linear regression and is used to measure the probability of a particular outcome rather than the actual outcome itself. Thus, its values are restricted to lie in the interval $[0,1]$ by the logistic distribution function. This model is appropriate when the dependent variable is dichotomous in nature and takes on values of one or zero. Owing to the dependent variable's binary nature, the conditional probability follows a Bernoulli distribution in a logit regression.

Distrust toward the EU is one of our dependent variables and takes the following values:

$$
\text { distrust towards } E U= \begin{cases}1 & \text { If a persondistrusts the } E U \\ 0 & \text { Otherwise }\end{cases}
$$

Here, zero represents a positive response (trust), and one represents a negative response (distrust). The mean of the dependent variable is the probability of distrust toward the EU. If $p$ is the probability of distrusting the EU, then $1-p$ is the probability of trusting the EU. The ratio of these two probabilities (i.e., $\frac{p}{1-p}$ ) is known as the odds, and the logarithm of the odds is the logit. The mathematical representation of the logit is as follows:

4) The data are provided at https://www.britishelectionstudy.com. 


$$
l=\operatorname{logit}(p)=\ln \left[\frac{p}{1-p}\right]
$$

By taking the dependent variable from the above equation and regressing it on the set of independent variables, we obtain the general form of the logit model:

$$
\ln \left[\frac{p}{1-p}\right]=\alpha+\beta X_{i t}+u_{i}
$$

where logit follows the (cumulative)logistic distribution. Because we aim to analyze probabilities, we transform equation (2) using the exponential function on both sides of the equation to obtain

$$
p=\frac{1}{1+e^{-z}}
$$

where $z=\beta_{0}+\beta_{i} X_{i t}+\mu_{i}$.

Equation (3) represents our baseline model specification and verifies the non-linear relationship between the dependent variable, expressed as a probability, and the set of independent variables. ${ }^{5}$ )

Our specification for measuring the probability of distrusting the EU is therefore

$$
p(\text { distrust })=\frac{1}{1+e^{-z}}
$$

where $z$ is the set of independent covariates:

$$
z=\beta_{0}+\beta_{1} \text { Gender }_{i(t)}+\beta_{2} \text { Age }_{i(t)}+\beta_{3} \text { Education }_{i(t)}+\beta_{3} \text { Marital-status }_{i(t)}+\beta_{4} \text { Occupation }_{i(t)}+
$$
$\beta_{5}$ Region $_{i(t)}+\beta_{6}$ EUmeaning-loss cultural ID $_{i(t)}+\beta_{7}$ Political Ideology $i(t)+\mu_{i}$.

The probability of voting in favor of Brexit is therefore measured as:

$$
\begin{aligned}
& p\left(\text { leave }=\frac{1}{1+e^{-z}}\right. \\
& z=\beta_{0}+\beta_{1} \text { Gender }_{i(t)}+\beta_{2} \text { Age }_{i(t)}+\beta_{3} \text { Education }_{i(t)}+\beta_{3} \text { Marital-status }_{i(t)}+\beta_{4} \text { Country }_{i(t)} \\
& \quad+\beta_{5} \text { HH }_{\text {income }} i(t)+\mu_{i} \text {. }
\end{aligned}
$$

5) Gujarati, D. N., Porter, D. C., \& Gunasekar, S. (2012) Basic econometrics. Tata McGraw-Hill Education. 
Tables 2 and 3 show summary statistics for distrust in the EU from the Eurobarometer dataset and for the Leave vote decision from the British Election Study dataset. We show the mean, standard deviation, and total number of observations for each variable and wave. For distrust (Table 2), we consider all available observations for the pre-referendum period (i.e., from 1997 to May 2016). For the election survey (Table 3), we report data for the two pre-Brexit waves with available data (i.e., April and June 2016).

As Table 2 shows, the level of distrust in the EU has relatively high standard errors, indicating large variations in opinions within almost all categories of people. Nevertheless, older people tend to exhibit a higher degree of distrust on average, whereas the people who are still in school and those with very high levels of education tend to exhibit much lower degrees of distrust. In terms of occupation categories, retired people have the highest average degrees of distrust. In terms of marital status, widow and divorced people express relatively high levels of distrust, whereas single and married people have lower levels of distrust. The middle class expresses the highest degree of distrust, and people from the center and the right of the political spectrum shows a higher degree of distrust than people placing themselves on the left side of the spectrum do. Additionally, as can be expected, people who do not feel "European" at all and those who think that belonging to the EU implies a loss of identity express very high levels of distrust in the EU on average.

Turning to opinions in favor of a Leave vote, Table 3 shows that these opinions are also expressed more strongly by older people on average. We find the same patterns as in the case of distrust toward the EU for people who are less educated and people who tend to express lower levels of pro-Brexit feelings. Among occupational categories, white-collar individuals have the lowest tendency to vote for Leave on average. People belong to lowest income quartile show the highest tendency to vote in favor of Brexit relative to the other income groups. Divorced and widowed respondents have stronger pro-Brexit opinions relative to the other marital status categories. We find that people on the right side of the political spectrum have higher degrees of pro-Brexit attitudes. In line with this finding, supporters of the UK Independence Party have a higher level of pro-Brexit expression, whereas the opposite holds for supporters of the Liberal Democrats. In line with the literature cited above, we also find that people who think that immigration will be lower if Brexit occurs express more support for the decision to leave. People who think that leaving the EU may help to reduce unemployment display greater support for the Leave decision. This set of findings in itself tends to support the interpretation that reasons for supporting Brexit are not only economic even though the literature shows that these determinants can be important.

We now turn to the empirical analysis to check if the patterns revealed by the descriptive statistics are statistically significant and understand how they have evolved over time. 
Table 2. Distrust in the EU - Pre-referendum Descriptive Statistics

\begin{tabular}{|c|c|c|c|}
\hline Variable & Mean & Standard Error & Frequency \\
\hline \multicolumn{4}{|l|}{ Gender } \\
\hline Male & 0.713 & 0.452 & 14,570 \\
\hline Female & 0.724 & 0.447 & 14,827 \\
\hline \multicolumn{4}{|l|}{ Age } \\
\hline $15-35$ & 0.591 & 0.491 & 8,276 \\
\hline $36-55$ & 0.719 & 0.449 & 8,797 \\
\hline $56-65$ & 0.801 & 0.398 & 4,681 \\
\hline $65+$ & 0.805 & 0.396 & 7,593 \\
\hline \multicolumn{4}{|l|}{ Education } \\
\hline Up to 15 & 0.813 & 0.389 & 8,017 \\
\hline $16-19$ & 0.748 & 0.433 & 13,443 \\
\hline $20+$ & 0.608 & 0.488 & 5,888 \\
\hline Still Studying & 0.438 & 0.496 & 1,690 \\
\hline \multicolumn{4}{|l|}{ Marital status } \\
\hline Single & 0.637 & 0.480 & 8,741 \\
\hline Married & 0.740 & 0.438 & 13,276 \\
\hline Divorced & 0.767 & 0.767 & 2,185 \\
\hline Widowed & 0.800 & 0.800 & 2,813 \\
\hline \multicolumn{4}{|l|}{ Occupation } \\
\hline White Collar & 0.671 & 0.469 & 8,035 \\
\hline Blue Collar & 0.738 & 0.439 & 5,855 \\
\hline Unemployed & 0.704 & 0.456 & 2,043 \\
\hline Retired & 0.802 & 0.397 & 9,534 \\
\hline Student & 0.587 & 0.492 & 3,930 \\
\hline \multicolumn{4}{|l|}{ Region } \\
\hline Scotland & 0.689 & 0.462 & 2,351 \\
\hline North, Yorks, Humberside, and North West & 0.749 & 0.433 & 7,343 \\
\hline East and West Midlands, East Anglia & 0.740 & 0.438 & 7,334 \\
\hline Wales & 0.728 & 0.444 & 1,046 \\
\hline South East and London & 0.672 & 0.469 & 8,505 \\
\hline South West & 0.733 & 0.442 & 2,520 \\
\hline \multicolumn{4}{|l|}{ Social Class } \\
\hline Lower Class & 0.741 & 0.438 & 5,726 \\
\hline Middle Class & 0.795 & 0.403 & 5,623 \\
\hline Upper Class & 0.750 & 0.432 & 3,005 \\
\hline \multicolumn{4}{|l|}{ Household financial situation } \\
\hline $\mathrm{Bad}$ & 0.802 & 0.397 & 3,591 \\
\hline Good & 0.732 & 0.443 & 14,275 \\
\hline \multicolumn{4}{|l|}{ Personal issues-immigration } \\
\hline Not mentioned & 0.680 & 0.466 & 15,239 \\
\hline Mentioned & 0.830 & 0.375 & 7,804 \\
\hline \multicolumn{4}{|l|}{ EU meaning-loss of cultural identity } \\
\hline Not mentioned & 0.668 & 0.470 & 17,856 \\
\hline Mentioned & 0.895 & 0.306 & 5,965 \\
\hline
\end{tabular}


Table 2. Continued

\begin{tabular}{|c|c|c|c|}
\hline Variable & Mean & Standard Error & Frequency \\
\hline \multicolumn{4}{|c|}{ Political placement } \\
\hline Left Wing & 0.608 & 0.488 & 6,255 \\
\hline Center & 0.713 & 0.452 & 11,061 \\
\hline Right Wing & 0.784 & 0.411 & 4,737 \\
\hline \multicolumn{4}{|c|}{ Support for the UK Independence Party } \\
\hline Strong & 0.948 & 0.424 & 17,080 \\
\hline Medium & 0.767 & 0.422 & 6,040 \\
\hline Low & 0.236 & 0.221 & 6,961 \\
\hline \multicolumn{4}{|c|}{ Support for Liberal Democrats } \\
\hline Strong & 0.270 & 0.475 & 14,062 \\
\hline Medium & 0.410 & 0.491 & 11,708 \\
\hline Low & 0.655 & 0.444 & 3,747 \\
\hline
\end{tabular}

(Source) Authors' calculation based on Eurobarometer Survey, 1997 to May 2016.

Table 3. Leave Vote - Pre-referendum Descriptive Statistics

\begin{tabular}{|c|c|c|c|}
\hline Variable & Mean & Standard Error & Frequency \\
\hline \multicolumn{4}{|l|}{ Gender } \\
\hline Male & 0.518 & 0.499 & 15,557 \\
\hline Female & 0.500 & 0.500 & 15,451 \\
\hline \multicolumn{4}{|l|}{ Age } \\
\hline $15-35$ & 0.344 & 0.475 & 4,043 \\
\hline $36-55$ & 0.534 & 0.498 & 4,224 \\
\hline $56-65$ & 0.589 & 0.492 & 2,742 \\
\hline $65+$ & 0.634 & 0.481 & 1,984 \\
\hline \multicolumn{4}{|l|}{ Education } \\
\hline Up to 15 & 0.735 & 0.440 & 2,984 \\
\hline $16-19$ & 0.611 & 0.487 & 11,795 \\
\hline $20+$ & 0.330 & 0.470 & 8,462 \\
\hline Still Studying & 0.212 & 0.409 & 1,179 \\
\hline \multicolumn{4}{|l|}{ Marital status } \\
\hline Single & 0.391 & 0.488 & 6,334 \\
\hline Married & 0.533 & 0.498 & 17,880 \\
\hline Divorced & 0.567 & 0.495 & 2,781 \\
\hline Widowed & 0.624 & 0.484 & 1,057 \\
\hline \multicolumn{4}{|l|}{ Occupation } \\
\hline White Collar & 0.418 & 0.493 & 4,467 \\
\hline Blue Collar & 0.510 & 0.499 & 9,121 \\
\hline Intermediate & 0.548 & 0.497 & 7,163 \\
\hline Semi-routine & 0.604 & 0.489 & 2,514 \\
\hline Routine & 0.653 & 0.476 & 1,416 \\
\hline \multicolumn{4}{|l|}{ Region } \\
\hline England & 0.536 & 0.498 & 23,102 \\
\hline Scotland & 0.370 & 0.482 & 3,913 \\
\hline Wales & 0.476 & 0.499 & 2,327 \\
\hline
\end{tabular}


Table 3. Continued

\begin{tabular}{|c|c|c|c|}
\hline Variable & Mean & Standard Error & Frequency \\
\hline \multicolumn{4}{|l|}{ Household income quartile } \\
\hline Lowest Quartile (--) & 0.541 & 0.498 & 7,474 \\
\hline Upper Lowest (-) & 0.483 & 0.499 & 8,341 \\
\hline Lower Highest $(+)$ & 0.425 & 0.494 & 2,729 \\
\hline Highest Quartile $(++)$ & 0.379 & 0.485 & 783 \\
\hline \multicolumn{4}{|c|}{ Immigrants are a burden on the welfare state } \\
\hline Disagree & 0.103 & 0.304 & 8,003 \\
\hline Neither agree nor disagree & 0.413 & 0.492 & 5,754 \\
\hline Agree & 0.754 & 0.754 & 16,071 \\
\hline \multicolumn{4}{|l|}{ Identity feelings } \\
\hline Strongly European & 0.694 & 0.460 & 20,084 \\
\hline Not at all European & 0.155 & 0.362 & 10,413 \\
\hline \multicolumn{4}{|c|}{ EU meaning-loss of cultural identity } \\
\hline Not mentioned & 0.263 & 0.440 & 15,752 \\
\hline Mentioned & 0.789 & 0.407 & 14,241 \\
\hline \multicolumn{4}{|l|}{ Political placement } \\
\hline Left Wing & 0.233 & 0.423 & 1,438 \\
\hline Center & 0.512 & 0.499 & 1,846 \\
\hline Right Wing & 0.757 & 0.428 & 1,456 \\
\hline \multicolumn{4}{|c|}{ Effect of Brexit on immigration } \\
\hline Low & 0.733 & 0.442 & 17,522 \\
\hline Remain the same & 0.167 & 0.373 & 9,556 \\
\hline \multicolumn{4}{|c|}{ Effect of Brexit on unemployment } \\
\hline Low & 0.860 & 0.346 & 7,032 \\
\hline Remain the same & 0.641 & 0.479 & 12,374 \\
\hline \multicolumn{4}{|c|}{ Effect of Brexit on the UK's overall economic situation } \\
\hline Worse & 0.0513 & 0.220 & 11,812 \\
\hline Remain the same & 0.749 & 0.433 & 9,507 \\
\hline Better & 0.941 & 0.234 & 7,587 \\
\hline
\end{tabular}

(Source) Authors' calculation based on wave 8 of the British Election Study.

\section{Pre-Brexit Determinants: Results}

\section{A. Regression analysis}

We now turn to the empirical analysis. Tables 4 and 5 report the predictive margins associated with our logit estimates.6) We include time fixed effects in the analyses shown in Table 4, which cover the period from 1997 to 2019. In Table 5, we present the results of a cross-sectional analysis considering the determinants of the Brexit vote during the time of the referendum.7)

6) Recall that Tables 4 and 5 display predictive margins (i.e., absolute probabilities). Thus, no categories are omitted. 
When calculating the predictive margins in Tables 4 and 5, we obtain the absolute probability of expressing distrust toward the EU and of voting for the Leave option, respectively, for all of the categories of a given variable.

Table 4 reports the results for the periods 1997 to 2006, 2007 to 2011, 2012 to 2014, 2015 to May 2016, and November 2016 to 2019. Our intention is to capture the historical determinants of distrust in the EU in the first period and then check whether these determinants were impacted by the financial and euro crises (2007-2011) or evolved before and after the Brexit period (i.e., pre- and post-referendum). In Table 5, the periods are shorter by definition, and we report four estimates: one for April 2016 (before the referendum), one for June 2016 (after the referendum), and two more in June 2017 and March 2019. We use these estimates to assess how preferences may have shifted after the decision was taken and throughout the process of negotiations with the EU.

Both tables display predictive margins along with their interpretations in percentages for ease of use. Moreover, our analysis includes a time dimension because we compare survey-based data across periods. Thus, the evolutions of the dependent variables can also be evaluated in some respects by examining the evolutions of the predictive margins. ${ }^{8)}$

Looking first at Table 4, we observe that gender is significant only during the crisis period and is not a determinant of distrust in the EU before or after this period. However, age is always an important determinant of distrust in the EU; if anything, the youngest cohort tends to be even less distrustful after the referendum.9) The level of education also has significant effects in all periods. Again, the only notable evolution is that the relative coefficient of the "still studying" category is increasing post-Brexit. Interestingly, although the respondent's occupation has strongly significant effects before and after the crisis and until the most recent period in our data, it does not have significant effects in the most recent period. We observe the opposite trend for marital status, which starts having a significant effect after the crisis period.

Regional variables are significant determinants of distrust in the EU before the financial and euro crises and after the referendum but not in the periods between the crises and the

7) The independent variables are selected based on the previous studies cited in the introduction. These variables are self-explanatory from their labels and have been shown to be relevant for explaining the patterns in votes in favor of Brexit. The variables are not always exactly the same in our two data sources, and we therefore select the most similar variables, followed by the most similar categories. We conduct variance inflation factor tests to check for collinearity issues. Additionally, we use Wald tests to verify whether the explanatory variables contribute significantly to the models that we run. Only marital status and gender make no significant contributions in almost all of the estimates (meaning that removing them does not affect or harm our models' significance). The results of all of these tests are available upon request.

8) See the previous footnote related to the Wald tests, which show whether each variable of interest makes a significant contribution. For instance, gender and marital status are insignificant in explaining the evolution of distrust, but they make significant contributions in the case of the evolution of Leave votes.

9) Recall that this dataset is not a true panel. Thus, comparing coefficients across columns is not meaningful, although the relative sizes of the coefficients for a given category (e.g., age) across columns may be considered to reveal some information, 
referendum. This finding may indicate that even if the financial crisis affected all of the UK, with consequences on the financial and banking systems, the consequences of the adjustments to the crisis and the consequences of the Brexit decision were not felt the same in all locations. This finding confirms Fetzer's (2019) analysis of the impacts of the austerity measures taken by the British government and how they have fed resentment regarding the role of the EU, which has likely served as an easy scapegoat.

As may be expected, political placement is strongly significant in all periods. The predictive margin associated with holding right-wing views is greater than those associated with other views for the entire period of observation.

Finally, positions on and perceptions of the EU play a significant role in determining the level of distrust toward this institution. Again, this relationship is verified for the whole period, and the analysis reveals that less favorable perceptions of the EU are greater predictors of distrust.

In the analysis of the determinants of Leave votes (Table 5), all of the variables considered always have strongly significant effects, as mentioned previously. Hence, any evolution that may be captured in the data can be observed by comparing the relative margins across columns, subject to all of the restrictions associated with the use of a pseudo-panel.

This investigation reveals, for example, that the relative importance of gender does not really change over time. The ratio of the predictive margin for women to that for men appears to equal 0.93 for the first wave and 0.92 for the last wave. Hence, the importance of gender in determining preferences for leaving the EU does not really vary over the period analyzed.

Conducting the same analysis for age reveals that the coefficients for all of the other categories are greater than that for the youngest cohort (i.e., 15-35 years old) and that this predictive margin has increased over time. For example, in wave 7 in 2016, the ratio of the predictive margin of respondents aged 65+ to that for respondents aged 15 to 35 is 1.42 (i.e., $42 \%$ higher for the older cohort). In wave 15 from March 2019, however, this ratio equals 1.85 (i.e., $85 \%$ higher for the older cohort). This result both confirms and strengthens Eichengreen et al.'s (2021) examination of the role of cohorts in maintaining preferences for Brexit, as it reveals that variation in preferences across ages may be changing more quickly than pure demographics trends may predict. We investigate this idea more deeply in the subsequent discussion. 
Table 4. Predictive Margins of the Determinants of Distrust in the EU

\begin{tabular}{|c|c|c|c|c|c|c|}
\hline & \multicolumn{4}{|c|}{ Before Referendum } & \multicolumn{2}{|r|}{ After Referendum } \\
\hline & $1997-2006$ & 2007-2011 & 2012-2014 & 2015-Мay & 2016 & Nov 2016-2019 \\
\hline \multicolumn{7}{|l|}{ Gender } \\
\hline Male & $\begin{array}{c}0.663 \\
(0.008)\end{array}$ & $\begin{array}{c}0.709 \\
(0.008)\end{array}$ & $\begin{array}{c}0.767 \\
(0.011)\end{array}$ & $\begin{array}{c}0.727 \\
(0.012)\end{array}$ & & $\begin{array}{c}0.659 \\
(0.010)\end{array}$ \\
\hline Female & $\begin{array}{c}0.652 \\
(0.008)\end{array}$ & $\begin{array}{c}0.720 \\
(0.008)\end{array}$ & $\begin{array}{c}0.772 \\
(0.012)\end{array}$ & $\begin{array}{c}0.700 \\
(0.013)\end{array}$ & & $\begin{array}{c}0.676 \\
(0.010)\end{array}$ \\
\hline \multicolumn{7}{|l|}{ Age } \\
\hline $15-35$ & $\begin{array}{c}0.608 \\
(0.012)\end{array}$ & $\begin{array}{c}0.674 \\
(0.015)\end{array}$ & $\begin{array}{c}0.715 \\
(0.023)\end{array}$ & $\begin{array}{c}0.650 \\
(0.026)\end{array}$ & & $\begin{array}{c}0.617 \\
(0.019)\end{array}$ \\
\hline $36-55$ & $\begin{array}{c}0.655 \\
(0.010)\end{array}$ & $\begin{array}{c}0.725 \\
(0.012)\end{array}$ & $\begin{array}{c}0.793 \\
(0.017)\end{array}$ & $\begin{array}{c}0.693 \\
(0.021)\end{array}$ & & $\begin{array}{c}0.665 \\
(0.015)\end{array}$ \\
\hline $56-65$ & $\begin{array}{c}0.703 \\
(0.015)\end{array}$ & $\begin{array}{c}0.752 \\
(0.014)\end{array}$ & $\begin{array}{c}0.845 \\
(0.020)\end{array}$ & $\begin{array}{c}0.783 \\
(0.022)\end{array}$ & & $\begin{array}{c}0.697 \\
(0.019)\end{array}$ \\
\hline $65+$ & $\begin{array}{c}0.714 \\
(0.017) \\
\end{array}$ & $\begin{array}{c}0.720 \\
(0.017)\end{array}$ & $\begin{array}{c}0.755 \\
(0.027)\end{array}$ & $\begin{array}{c}0.751 \\
(0.024) \\
\end{array}$ & & $\begin{array}{c}0.698 \\
(0.020)\end{array}$ \\
\hline \multicolumn{7}{|l|}{ Education } \\
\hline Up to 15 & $\begin{array}{c}0.706 \\
(0.011)\end{array}$ & $\begin{array}{c}0.794 \\
(0.012)\end{array}$ & $\begin{array}{c}0.847 \\
(0.018)\end{array}$ & $\begin{array}{c}0.758 \\
(0.021)\end{array}$ & & $\begin{array}{c}0.778 \\
(0.017)\end{array}$ \\
\hline $16-19$ & $\begin{array}{c}0.680 \\
(0.008)\end{array}$ & $\begin{array}{c}0.745 \\
(0.009)\end{array}$ & $\begin{array}{c}0.779 \\
(0.013)\end{array}$ & $\begin{array}{c}0.752 \\
(0.013)\end{array}$ & & $\begin{array}{c}0.695 \\
(0.011)\end{array}$ \\
\hline $20+$ & $\begin{array}{c}0.577 \\
(0.015)\end{array}$ & $\begin{array}{c}0.620 \\
(0.014)\end{array}$ & $\begin{array}{c}0.723 \\
(0.017)\end{array}$ & $\begin{array}{c}0.648 \\
(0.019)\end{array}$ & & $\begin{array}{c}0.569 \\
(0.014)\end{array}$ \\
\hline Still studying & $\begin{array}{c}0.504 \\
(0.029)\end{array}$ & $\begin{array}{c}0.489 \\
(0.044)\end{array}$ & $\begin{array}{c}0.660 \\
(0.070)\end{array}$ & $\begin{array}{c}0.596 \\
(0.072) \\
\end{array}$ & & $\begin{array}{c}0.668 \\
(0.050)\end{array}$ \\
\hline \multicolumn{7}{|l|}{ Marital status } \\
\hline Single & $\begin{array}{c}0.650 \\
(0.010)\end{array}$ & $\begin{array}{c}0.697 \\
(0.012)\end{array}$ & $\begin{array}{c}0.761 \\
(0.016)\end{array}$ & $\begin{array}{c}0.731 \\
(0.016)\end{array}$ & & $\begin{array}{c}0.671 \\
(0.013)\end{array}$ \\
\hline Married & $\begin{array}{c}0.656 \\
(0.009)\end{array}$ & $\begin{array}{c}0.722 \\
(0.008)\end{array}$ & $\begin{array}{c}0.763 \\
(0.012)\end{array}$ & $\begin{array}{c}0.697 \\
(0.012)\end{array}$ & & $\begin{array}{c}0.668 \\
(0.010)\end{array}$ \\
\hline Divorced & $\begin{array}{c}0.687 \\
(0.017)\end{array}$ & $\begin{array}{c}0.718 \\
(0.021)\end{array}$ & $\begin{array}{c}0.884 \\
(0.032)\end{array}$ & $\begin{array}{c}0.737 \\
(0.042)\end{array}$ & & $\begin{array}{c}0.684 \\
(0.030)\end{array}$ \\
\hline Widowed & $\begin{array}{c}0.667 \\
(0.021)\end{array}$ & $\begin{array}{c}0.728 \\
(0.021)\end{array}$ & $\begin{array}{c}0.779 \\
(0.032)\end{array}$ & $\begin{array}{c}0.741 \\
(0.032)\end{array}$ & & $\begin{array}{c}0.630 \\
(0.028)\end{array}$ \\
\hline \multicolumn{7}{|l|}{ Occupation } \\
\hline White collar & $\begin{array}{c}0.647 \\
(0.012)\end{array}$ & $\begin{array}{c}0.689 \\
(0.012)\end{array}$ & $\begin{array}{c}0.749 \\
(0.018)\end{array}$ & $\begin{array}{c}0.712 \\
(0.018)\end{array}$ & & $\begin{array}{c}0.663 \\
(0.014)\end{array}$ \\
\hline Blue collar & $\begin{array}{c}0.677 \\
(0.012)\end{array}$ & $\begin{array}{c}0.739 \\
(0.015)\end{array}$ & $\begin{array}{c}0.789 \\
(0.022)\end{array}$ & $\begin{array}{c}0.765 \\
(0.021)\end{array}$ & & $\begin{array}{c}0.703 \\
(0.018)\end{array}$ \\
\hline Unemployed & $\begin{array}{c}0.653 \\
(0.023)\end{array}$ & $\begin{array}{c}0.723 \\
(0.022)\end{array}$ & $\begin{array}{c}0.780 \\
(0.035)\end{array}$ & $\begin{array}{c}0.675 \\
(0.037)\end{array}$ & & $\begin{array}{c}0.664 \\
(0.033)\end{array}$ \\
\hline Retired & $\begin{array}{c}0.658 \\
(0.015)\end{array}$ & $\begin{array}{c}0.717 \\
(0.014)\end{array}$ & $\begin{array}{c}0.790 \\
(0.022)\end{array}$ & $\begin{array}{c}0.695 \\
(0.024)\end{array}$ & & $\begin{array}{c}0.680 \\
(0.018)\end{array}$ \\
\hline Student & $\begin{array}{c}0.648 \\
(0.016)\end{array}$ & $\begin{array}{c}0.729 \\
(0.025)\end{array}$ & $\begin{array}{c}0.728 \\
(0.046)\end{array}$ & $\begin{array}{c}0.719 \\
(0.046)\end{array}$ & & $\begin{array}{c}0.566 \\
(0.039)\end{array}$ \\
\hline
\end{tabular}


Table 4. Continued

\begin{tabular}{|c|c|c|c|c|c|c|}
\hline & \multicolumn{4}{|c|}{ Before Referendum } & \multicolumn{2}{|r|}{ After Referendum } \\
\hline & 1997-2006 & 2007-2011 & 2012-2014 & 2015-May & 2016 & Nov 2016-2019 \\
\hline \multicolumn{7}{|l|}{ Region } \\
\hline Scotland & $\begin{array}{c}0.618 \\
(0.018)\end{array}$ & $\begin{array}{c}0.704 \\
(0.021)\end{array}$ & $\begin{array}{c}0.801 \\
(0.031)\end{array}$ & $\begin{array}{c}0.733 \\
(0.032)\end{array}$ & & $\begin{array}{c}0.628 \\
(0.027)\end{array}$ \\
\hline North, Yorks, and North West & $\begin{array}{c}0.668 \\
(0.011)\end{array}$ & $\begin{array}{c}0.767 \\
(0.011)\end{array}$ & $\begin{array}{c}0.776 \\
(0.015)\end{array}$ & $\begin{array}{c}0.759 \\
(0.017)\end{array}$ & & $\begin{array}{c}0.685 \\
(0.015)\end{array}$ \\
\hline East and West Midlands, East Anglia & $\begin{array}{c}0.666 \\
(0.011)\end{array}$ & $\begin{array}{c}0.715 \\
(0.011)\end{array}$ & $\begin{array}{c}0.792 \\
(0.017)\end{array}$ & $\begin{array}{c}0.688 \\
(0.017)\end{array}$ & & $\begin{array}{c}0.693 \\
(0.013)\end{array}$ \\
\hline Wales & $\begin{array}{c}0.705 \\
(0.031)\end{array}$ & $\begin{array}{c}0.725 \\
(0.032)\end{array}$ & $\begin{array}{c}0.695 \\
(0.040)\end{array}$ & $\begin{array}{c}0.725 \\
(0.040)\end{array}$ & & $\begin{array}{c}0.722 \\
(0.032)\end{array}$ \\
\hline South East and London & $\begin{array}{c}0.650 \\
(0.010)\end{array}$ & $\begin{array}{c}0.666 \\
(0.011)\end{array}$ & $\begin{array}{c}0.752 \\
(0.017)\end{array}$ & $\begin{array}{c}0.690 \\
(0.017)\end{array}$ & & $\begin{array}{c}0.619 \\
(0.014)\end{array}$ \\
\hline South West & $\begin{array}{c}0.663 \\
(0.019)\end{array}$ & $\begin{array}{c}0.738 \\
(0.018)\end{array}$ & $\begin{array}{c}0.760 \\
(0.031) \\
\end{array}$ & $\begin{array}{c}0.725 \\
(0.032) \\
\end{array}$ & & $\begin{array}{c}0.707 \\
(0.023)\end{array}$ \\
\hline \multicolumn{7}{|l|}{ EU meaning a loss of cultural identity } \\
\hline Not mentioned & $\begin{array}{c}0.586 \\
(0.007)\end{array}$ & $\begin{array}{c}0.661 \\
(0.007)\end{array}$ & $\begin{array}{c}0.736 \\
(0.010)\end{array}$ & $\begin{array}{c}0.659 \\
(0.011)\end{array}$ & & $\begin{array}{c}0.628 \\
(0.008)\end{array}$ \\
\hline Mentioned & $\begin{array}{c}0.834 \\
(0.008)\end{array}$ & $\begin{array}{c}0.876 \\
(0.009)\end{array}$ & $\begin{array}{c}0.916 \\
(0.014)\end{array}$ & $\begin{array}{c}0.903 \\
(0.013)\end{array}$ & & $\begin{array}{c}0.870 \\
(0.014)\end{array}$ \\
\hline \multicolumn{7}{|l|}{ Political ideology } \\
\hline Left-wing & $\begin{array}{c}0.595 \\
(0.010)\end{array}$ & $\begin{array}{c}0.651 \\
(0.012)\end{array}$ & $\begin{array}{c}0.717 \\
(0.017)\end{array}$ & $\begin{array}{c}0.687 \\
(0.016)\end{array}$ & & $\begin{array}{c}0.594 \\
(0.013)\end{array}$ \\
\hline Center & $\begin{array}{c}0.669 \\
(0.007)\end{array}$ & $\begin{array}{c}0.728 \\
(0.008)\end{array}$ & $\begin{array}{c}0.792 \\
(0.011)\end{array}$ & $\begin{array}{c}0.721 \\
(0.013)\end{array}$ & & $\begin{array}{c}0.688 \\
(0.010)\end{array}$ \\
\hline Right-wing & $\begin{array}{c}0.721 \\
(0.012) \\
\end{array}$ & $\begin{array}{c}0.763 \\
(0.012)\end{array}$ & $\begin{array}{c}0.788 \\
(0.019) \\
\end{array}$ & $\begin{array}{c}0.739 \\
(0.019) \\
\end{array}$ & & $\begin{array}{c}0.739 \\
(0.016) \\
\end{array}$ \\
\hline \multicolumn{7}{|c|}{ Diagnostics } \\
\hline Wald Score & $\begin{array}{c}730.81 \\
(0.000)\end{array}$ & $\begin{array}{l}651.97 \\
(0.000)\end{array}$ & $\begin{array}{l}195.61 \\
(0.000)\end{array}$ & $\begin{array}{l}229.63 \\
(0.000)\end{array}$ & & $\begin{array}{l}437.30 \\
(0.000)\end{array}$ \\
\hline Pseudo-R2 & 0.1159 & 0.1470 & 0.1111 & 0.1129 & & 0.1219 \\
\hline Observations & 6,224 & 4,844 & 2,121 & 2,244 & & 3,649 \\
\hline
\end{tabular}

The role of education is changing much less dramatically. The lowest ratio is obtained when comparing the predictive margin for people with more than 20 years of education to that for people with up to 15 years of education, and its value does not change much over time; it is 0.60 for the first wave and 0.57 for the last wave. The role of marital status similarly does not change very much, with the predictive margin for single people being generally lower than those for the other modalities in this category.

Regions do matter, and our analysis here confirms the findings of, for example, Alabrese et al. (2019) and Fidrmuc et al. (2019).10) England is clearly the most pro-Brexit part of the

10) Although our data do not allow us to differentiate the results at very local levels (e.g., between central London and some of its suburbs), they do confirm the broad picture revealed by studies that use such detailed data (e.g., Los et al., 2017). 
country, whereas Scotland is the most reluctant to leave the EU. The ratio of the predictive margins ranges from 0.70 and 0.73 for England and Scotland, suggesting a difference of 27 to 30 points, which is clearly not negligible.

Finally, for income quartiles, the predictive margin is clearly always greater for the lowest quartile, and the ratios are relatively constant over time. Interestingly, we do observe an exception for the highest quartile. In wave 7 of the survey, this quartile was the most in favor of the Leave option (the ratio of the predictive margins shows that it preferred the Leave option slightly more than the lowest quartile did). However, this relationship has changed considerably over time, as the ratio is now $12 \%$ lower for the highest income quartile. Hence, among all categories, preferences are most likely to have changed for the highest income quartile.

The conclusions that can be drawn from the two sets of estimates in Tables 4 and 5 are as follows. First, it appears that the determinants of pro-Brexit opinions and distrust toward the EU are basically the same (i.e., education, age, occupation, and political placement all play important roles). Second, the patterns that we reveal do not change substantially over the 20 years that our dataset on distrust toward the EU covers nor over the shorter period before and after the Brexit referendum campaign covered by the British Election Study. Moreover, the patterns of the determinants of attitudes and preferences do not seem to have changed in the post-Brexit period. This result is not very surprising even though some worries have arisen after the Brexit results (see Table 1), as the margin in favor of the Brexit decision has not changed very much since the referendum (see Figure 1).

Table 5. Predictive Margins of the Determinants of Leave Votes

\begin{tabular}{lcccc}
\hline & $\begin{array}{c}\text { Apr. 2016: } \\
\text { Wave 7 }\end{array}$ & $\begin{array}{c}\text { June 2016: } \\
\text { Wave 8 }\end{array}$ & $\begin{array}{c}\text { June 2017: } \\
\text { Wave 13 }\end{array}$ & $\begin{array}{c}\text { March 2019: } \\
\text { Wave 15 }\end{array}$ \\
\cline { 2 - 5 } Gender & $(\mathbf{1})$ & $\mathbf{( 2 )}$ & $\mathbf{( 3 )}$ & $\mathbf{( 4 )}$ \\
Male & & & & \\
& 0.512 & 0.500 & 0.448 & 0.492 \\
Female & $(0.004)$ & $(0.009)$ & $(0.005)$ & $(0.005)$ \\
& 0.477 & 0.458 & 0.420 & 0.455 \\
Age & $(0.004)$ & $(0.009)$ & $(0.005)$ & $(0.005)$ \\
$15-35$ & & & & 0.300 \\
36-55 & 0.385 & 0.391 & 0.272 & $(0.013)$ \\
56-65 & $(0.008)$ & $(0.013)$ & $(0.008)$ & 0.435 \\
& 0.495 & 0.507 & 0.417 & $(0.007)$ \\
$65+$ & $(0.005)$ & $(0.011)$ & $(0.006)$ & 0.504 \\
& 0.524 & 0.525 & 0.487 & $(0.008)$ \\
\hline
\end{tabular}


Table 5. Continued

\begin{tabular}{|c|c|c|c|c|}
\hline & $\begin{array}{c}\text { Apr. 2016: } \\
\text { Wave } 7\end{array}$ & $\begin{array}{c}\text { June 2016: } \\
\text { Wave } 8\end{array}$ & $\begin{array}{c}\text { June 2017: } \\
\text { Wave } 13\end{array}$ & $\begin{array}{l}\text { March 2019: } \\
\text { Wave 15 }\end{array}$ \\
\hline & (1) & (2) & (3) & (4) \\
\hline \multicolumn{5}{|c|}{ Education level (Baseline: Up to 15) } \\
\hline Up to 15 & $\begin{array}{c}0.671 \\
(0.009)\end{array}$ & $\begin{array}{c}0.704 \\
(0.053)\end{array}$ & $\begin{array}{c}0.598 \\
(0.018)\end{array}$ & $\begin{array}{c}0.647 \\
(0.013)\end{array}$ \\
\hline $16-19$ & $\begin{array}{c}0.577 \\
(0.004)\end{array}$ & $\begin{array}{c}0.585 \\
(0.020)\end{array}$ & $\begin{array}{c}0.534 \\
(0.005)\end{array}$ & $\begin{array}{c}0.542 \\
(0.005)\end{array}$ \\
\hline $20+$ & $\begin{array}{c}0.345 \\
(0.005)\end{array}$ & $\begin{array}{c}0.336 \\
(0.021)\end{array}$ & $\begin{array}{c}0.355 \\
(0.005)\end{array}$ & $\begin{array}{c}0.309 \\
(0.007)\end{array}$ \\
\hline Still studying & $\begin{array}{c}0.300 \\
(0.015) \\
\end{array}$ & $\begin{array}{c}0.233 \\
(0.059) \\
\end{array}$ & $\begin{array}{c}0.231 \\
(0.010) \\
\end{array}$ & $\begin{array}{c}0.321 \\
(0.028) \\
\end{array}$ \\
\hline \multicolumn{5}{|c|}{ Marital-status (Baseline: Married) } \\
\hline Single & $\begin{array}{c}0.478 \\
(0.006)\end{array}$ & $\begin{array}{c}0.473 \\
(0.013)\end{array}$ & $\begin{array}{c}0.447 \\
(0.004)\end{array}$ & $\begin{array}{c}0.448 \\
(0.009)\end{array}$ \\
\hline Married & $\begin{array}{c}0.497 \\
(0.003)\end{array}$ & $\begin{array}{c}0.479 \\
(0.008)\end{array}$ & $\begin{array}{c}0.389 \\
(0.008)\end{array}$ & $\begin{array}{c}0.479 \\
(0.005)\end{array}$ \\
\hline Divorced & $\begin{array}{c}0.512 \\
(0.009)\end{array}$ & $\begin{array}{c}0.493 \\
(0.021)\end{array}$ & $\begin{array}{c}0.439 \\
(0.011)\end{array}$ & $\begin{array}{c}0.470 \\
(0.012)\end{array}$ \\
\hline Widowed & $\begin{array}{c}0.510 \\
(0.015) \\
\end{array}$ & $\begin{array}{c}0.475 \\
(0.040) \\
\end{array}$ & $\begin{array}{c}0.458 \\
(0.019) \\
\end{array}$ & $\begin{array}{c}0.509 \\
(0.023)\end{array}$ \\
\hline \multicolumn{5}{|l|}{ Region } \\
\hline England & $\begin{array}{c}0.522 \\
(0.003)\end{array}$ & $\begin{array}{c}0.506 \\
(0.007)\end{array}$ & $\begin{array}{r}0.461 \\
(0.004)\end{array}$ & $\begin{array}{c}0.496 \\
(0.004)\end{array}$ \\
\hline Scotland & $\begin{array}{c}0.365 \\
(0.007)\end{array}$ & $\begin{array}{c}0.349 \\
(0.018)\end{array}$ & $\begin{array}{c}0.309 \\
(0.009)\end{array}$ & $\begin{array}{c}0.363 \\
(0.011)\end{array}$ \\
\hline Wales & $\begin{array}{c}0.460 \\
(0.010) \\
\end{array}$ & $\begin{array}{c}0.400 \\
(0.022) \\
\end{array}$ & $\begin{array}{c}0.378 \\
(0.012) \\
\end{array}$ & $\begin{array}{c}0.414 \\
(0.014) \\
\end{array}$ \\
\hline \multicolumn{5}{|c|}{ Household income quartile } \\
\hline Lowest quartile (--) & $\begin{array}{c}0.508 \\
(0.004)\end{array}$ & $\begin{array}{c}0.514 \\
(0.011)\end{array}$ & $\begin{array}{c}0.453 \\
(0.006)\end{array}$ & $\begin{array}{c}0.495 \\
(0.006)\end{array}$ \\
\hline Upper lowest (-) & $\begin{array}{c}0.464 \\
(0.005)\end{array}$ & $\begin{array}{c}0.465 \\
(0.009)\end{array}$ & $\begin{array}{c}0.438 \\
(0.007)\end{array}$ & $\begin{array}{c}0.464 \\
(0.006)\end{array}$ \\
\hline Lower highest $(+)$ & $\begin{array}{c}0.444 \\
(0.008)\end{array}$ & $\begin{array}{c}0.453 \\
(0.011)\end{array}$ & $\begin{array}{c}0.415 \\
(0.006)\end{array}$ & $\begin{array}{c}0.452 \\
(0.009)\end{array}$ \\
\hline Highest quartile $(++)$ & $\begin{array}{c}0.529 \\
(0.006)\end{array}$ & $\begin{array}{c}0.397 \\
(0.030)\end{array}$ & $\begin{array}{c}0.394 \\
(0.014)\end{array}$ & $\begin{array}{c}0.436 \\
(0.016)\end{array}$ \\
\hline \multicolumn{5}{|c|}{ Diagnostics } \\
\hline Wald score & $\begin{array}{c}2,959.67 \\
(0.000) \\
\end{array}$ & $\begin{array}{l}223.59 \\
(0.000) \\
\end{array}$ & $\begin{array}{c}1,706.00 \\
(0.000) \\
\end{array}$ & $\begin{array}{c}1627 \\
(0.000) \\
\end{array}$ \\
\hline Pseudo R2 & 0.0955 & 0.2240 & 0.0894 & 0.1049 \\
\hline Observations & 25,850 & 1,037 & 16,403 & 13,339 \\
\hline
\end{tabular}

Note: Cross-sectional analysis. The table shows predictive margins with standard errors in parentheses. 


\section{Post-Brexit Persistence? Results from an APC Analysis}

We conduct an APC analysis using our dataset to identify the effect of birth cohort on distrust over time. This analysis is important because if people tend to become more conservative over time, their tendencies to promote Eurosceptic views will increase over time as well. Although Glenn (1974) questions the relation between age and conservatism, their positive association is confirmed by, for example, Peterson et al. (2020). Schonfeld and Winter-Levy (2019) show that members of Britain's Conservative party tend to adopt more extreme and conservative views and that this trend has been exacerbated since the Brexit referendum.

A cohort effect is conceptualized as an interaction or effect modification due to a period effect being differentially experienced by different age groups through age-specific exposure or susceptibility to an event or cause. An APC model is an additive model in which the predictor is the sum of three time effects that are functions of age, period, and cohort. Our approach evaluates the interaction between period and birth cohort to avoid the standard identification problem in APC models that arises because the three terms can be perfectly collinear (e.g., Fannon \& Nielsen, 2019).

We include each available survey about distrust toward the EU and, for each respondent, we analyze the relation between distrust and birth cohort. First, we look at national data, as Eichengreen et al. (2021) do, and we then go deeper by looking at regional data.11) Because our results show that the age factor is substantial for the trends that we highlight, we use population forecasts to shed some light on the chances that this factor may persist or disappear over time.

\section{A. National-level analysis}

Figures $2 \mathrm{a}$ and $2 \mathrm{~b}$ display people's mean level of distrust by period interacted with birth cohorts. Each birth cohort is divided into five sub-cohorts. First, the birth cohort including people older than 70 in 2016 is divided into five sub-cohorts: 1926 to 1929,1930 to 1933,1934 to 1937, 1938 to 1941 , and 1942 to 1945 . The interaction of time with these sub-cohorts shows that distrust for people belonging to these cohorts is greater than $60 \%$ from 1997 to 2016 . The birth cohort for people who are ages 55 to 70 in 2016 is divided into four cohorts: 1946 to 1949, 1950 to 1953,1954 to 1957 , and 1958 to 1961 . The mean distrust for this cohort also remains above $60 \%$ for almost the entire study period. Moreover, their level of distrust increases over time, and the overlaps between the curves illustrate that distrust does not differ very much across the sub-cohorts. People ages 35 to 54 in 2016 are divided into five sub-cohorts: 1962 to 1965,1966 to 1969,1970 to 1973,1974 to 1977 , and 1978 to 1981 . Figure 2b shows that distrust for these cohorts increased during the financial crisis but has subsided afterwards. Finally, people ages 15 to 34 in 2016 are divided into five cohorts: 1982 to 1985,1986 to 1989,1990

11) All of the summary statistics for the national analysis are given in Tables $2 \mathrm{a}$ to $2 \mathrm{~d}$ in the Appendix. 
to 1993,1994 to 1997 , and 1998 to 2000 . Figure $2 \mathrm{~d}$ shows that the level of distrust is lower for more recent cohorts than for people belonging to earlier cohorts, although distrust is trending upward. In other words, it appears that as people grow older, their views of the EU tend to become increasingly less favorable.

The APC analysis of our survey data therefore reveals a generation gap (measured here by birth cohorts) in UK respondents' feelings of distrust toward the EU. We can conclude that people born in earlier cohorts are permanently characterized by a higher level of distrust relative to people that were born later. In other words, older people's distrust toward the EU remains greater than that of their younger fellow citizens. However, the level of distrust increases with age, and the slope of this increase is particularly steep for members of younger generations.

Figure 2a. Percent of distrust among people older than 70 over time with respect to birth cohort

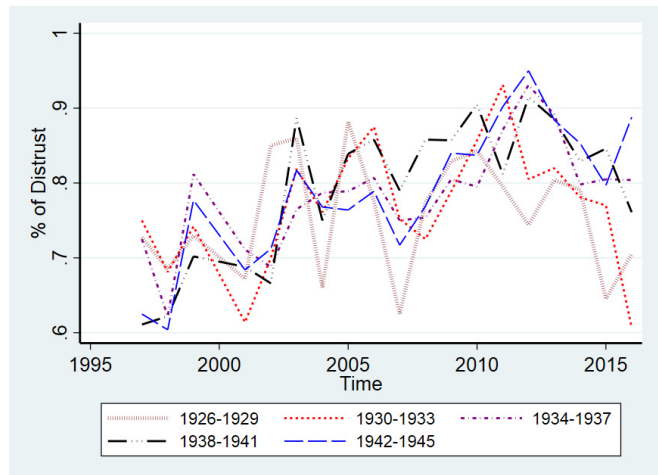

Note: For Figures 2a to 2d, the reference year is 2016.

Figure 2c. Percent of distrust for people aged 35-54 over time with respect to birth cohort

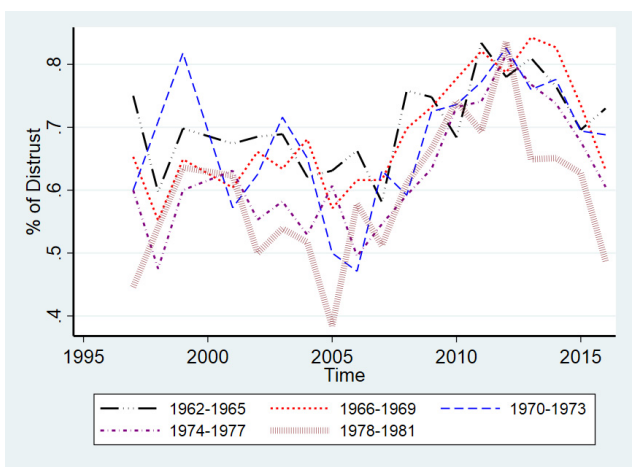

Figure 2b. Percent of distrust for people aged 55-70 over time with respect to birth cohort

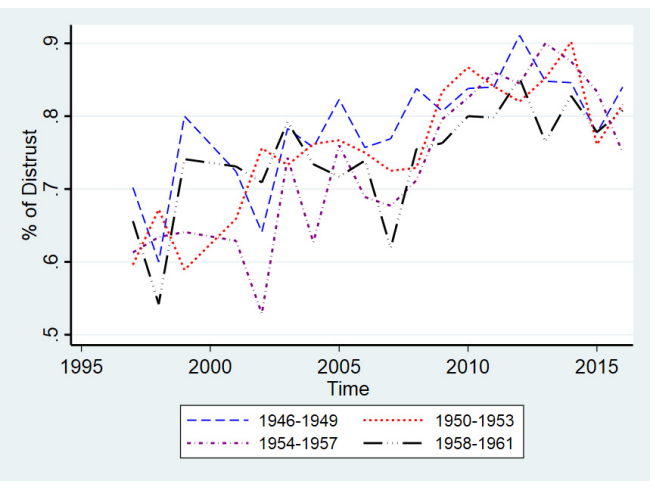

Figure 2d. Percent of distrust for people aged 15-34 over time with respect to birth cohort

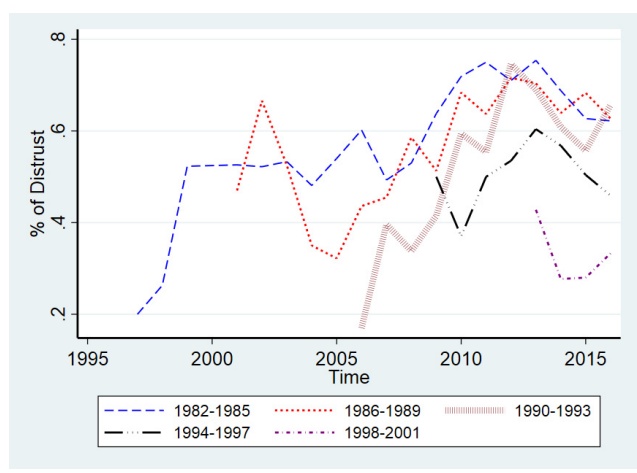




\section{B. Regional-level analysis}

Our data cover six regions: North, Yorks, Humberside, and North West; East and West Midlands and East Anglia; South East and London; South West; Scotland; and Wales.

Figure 3. Comparison of distrust and leave votes by region
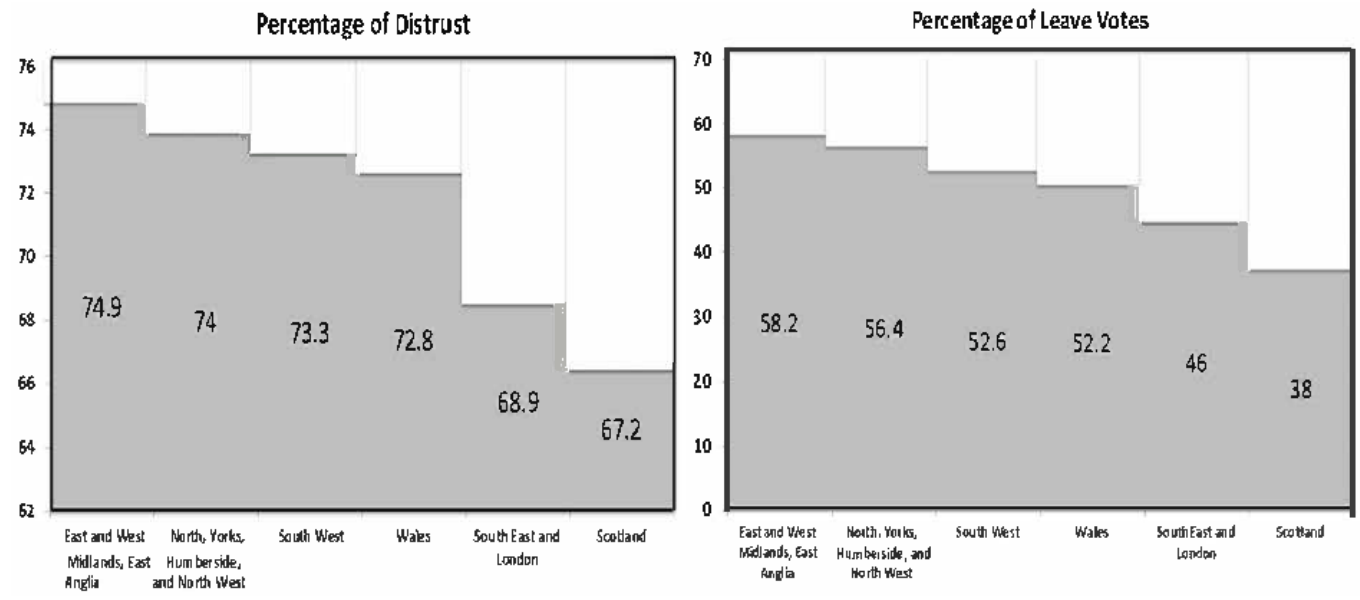

Figure 3 shows the percentages of people who voted in favor of Brexit and expressed distrust toward the EU by region. Although we observe a common pattern (regions with higher levels of distrust also have more votes in favor of Brexit), the striking feature emerging from this figure (confirming the results in Tables 4 and 5) is the large regional differences in the UK, with Scotland and the London area exhibiting much less Euroscepticism than the other regions.

Figures $4 \mathrm{a}$ to $4 \mathrm{c}$ show the three factors from the APC analysis for each region. We can observe that age has similar effects across regions, with older people being more distrustful than younger ones. Interestingly, this pattern also holds for the two less Eurosceptic regions mentioned above, the London area and Scotland. However, the cohort effect is different across regions. The cohort effect is the variation across people born at particular points in time that is independent of the aging process. In this case, the cohort effect varies across regions, as Figure $4 \mathrm{~b}$ shows; although the cohort effect is decreasing over the various cohorts in all regions, it reaches much lower levels in Scotland, Wales, and the London area. This effect does not compensate for the age effect, however, meaning that the global level of distrust tends to increase with age. The period effect, which affects all age groups and cohorts uniformly, is increasing from 1997 to the first decade of the $21^{\text {st }}$ century but decreases everywhere after 2010. However, it remains very high (i.e., distrust remains above 60\%), with the minimum being reached in the London area. The London area exhibits a distinct pattern from the other regions relative to this effect.

Our analysis therefore reveals that if people uniformly tend to be increasingly Eurosceptic 
as they grow older across the UK, the cohort effect tends to dampen the age effect in Scotland, Wales, and the London area, but it does not offset the age effect entirely. Additionally, a period effect tends to reduce Euroscepticism after 2010 but does not offset the effects of aging.

Figure 4a. Age effects across regions
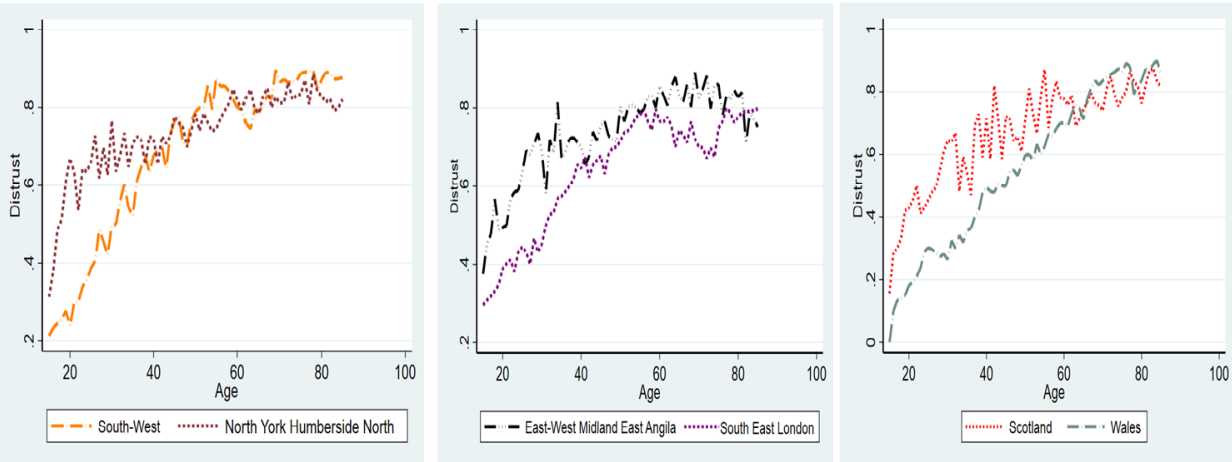

Figure 4b. Cohort effects across regions
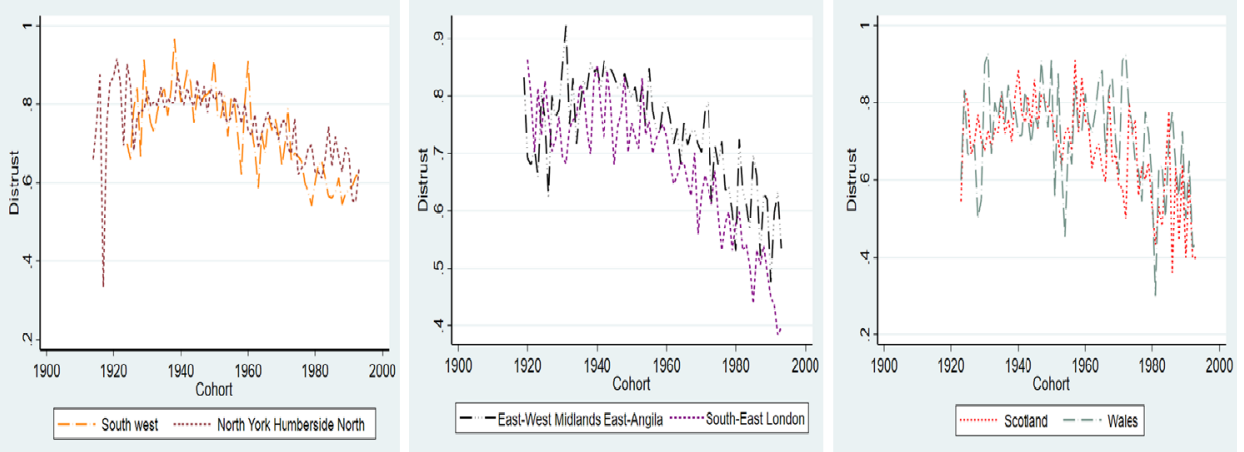

Figure 4c. Period effects across regions
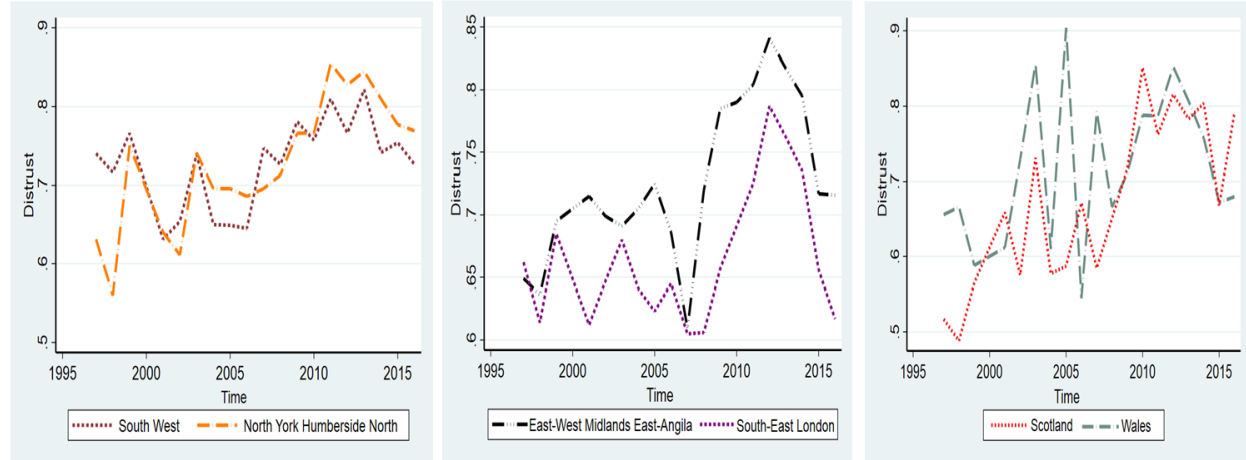

(Source) Authors' calculation based on Eurobarometer survey data from 1997 to 2016 


\section{Demographic facts and projections}

If age is a dominant factor, then the evolution of demographics will play an important role in the persistence or disappearance of Eurosceptic opinions in the UK. We therefore first analyze whether large regional disparities exist in terms of demographic profiles and then examine the forecasts to check whether any discernable orientations are present.

Figure 5 shows the demographic profiles of each region for the two extremes of the distribution (ages 0 to 15 and ages 65 and up) for the last 20 years. Tellingly, we observe large disparities between the regions, with the North West having the lowest share of young people overall and the Western Midlands showing a large decrease in the share of young people during this period. In parallel, London has had the lowest share of people older than 65 since 2008 and has reached a lower plateau since then, whereas the other regions all have an increasing share of the population over age 65. If conservatism (and, in this case, Euroscepticism) grows with age, then the regional age factors can largely be explained by these trends.

Figure 5a. Growth in the population aged $0-15$ by region
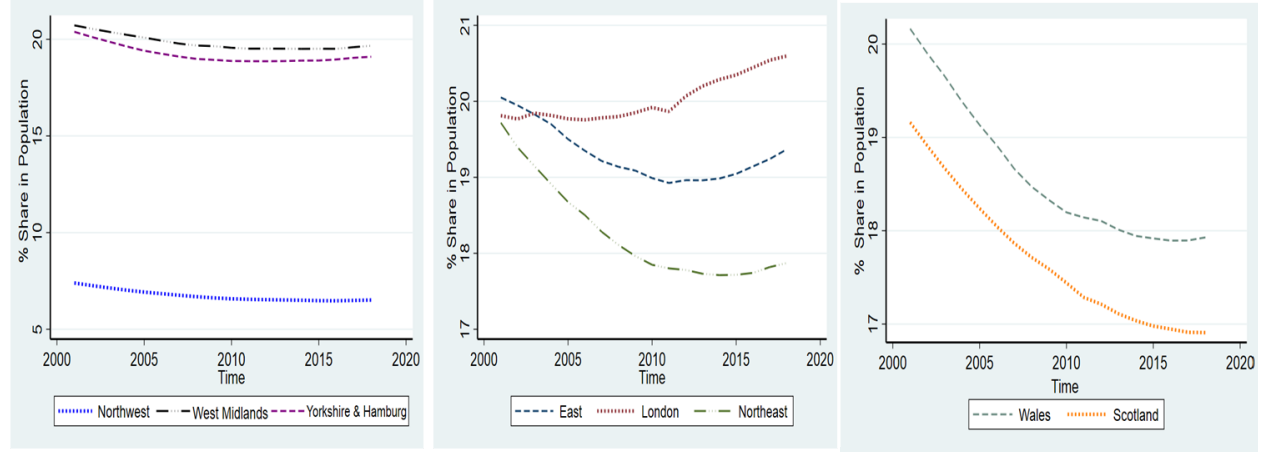

Figure 5b. Growth in the population over age 65 by region
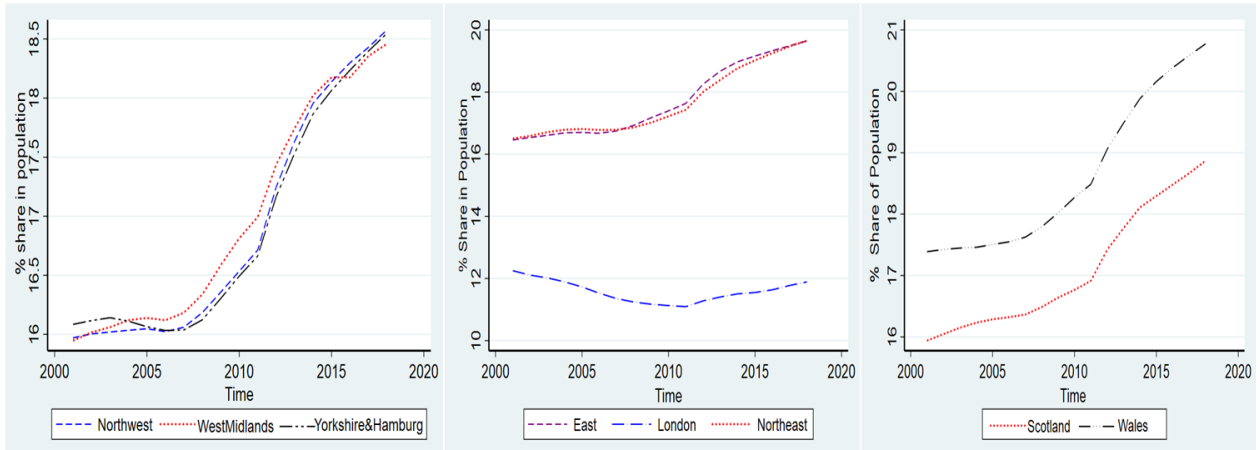

(Source) Authors' calculation based on ONS 
To help gauge the future of UK citizens' preferences with regard to the EU, Figure 6 shows that the UK population is increasingly aging and that this trend will continue over the next 30 years (based on forecasts through 2049). Moreover, people over age 50 make up an increasingly large share of the UK population, and the UK will have even more people at even older ages by mid-2049. The UK population over age 85 was 1.6 million in 2018 and is projected to nearly double to 3.0 million by mid-2049. This growth partly reflects a general increase in life expectancy as well as a reduction in fertility rates. ${ }^{12)}$ Figure 7 shows that the demographic dynamics will not change substantially in the less distrustful regions. Hence, in terms of our main research question, these patterns mean that the age factor will increasingly dominate, leading to more conservative and Eurosceptic preferences. In sum, this result does not support some people's belief that Brexit was only a momentary lapse of reason from UK citizens.

Figure 6. Demographic forecasts through 2049 for the UK
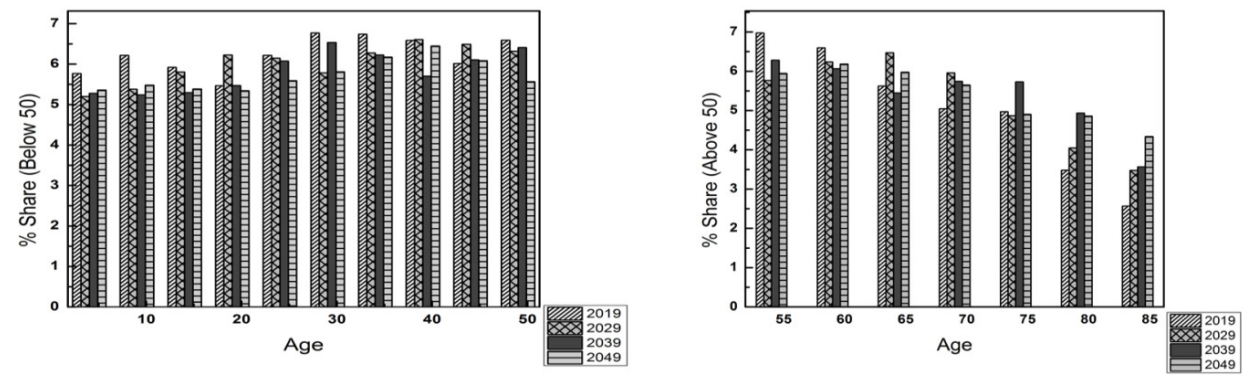

(Source) Authors' calculation based on Office for National Statistics data

Figure 7. Demographic forecasts through 2049 by region
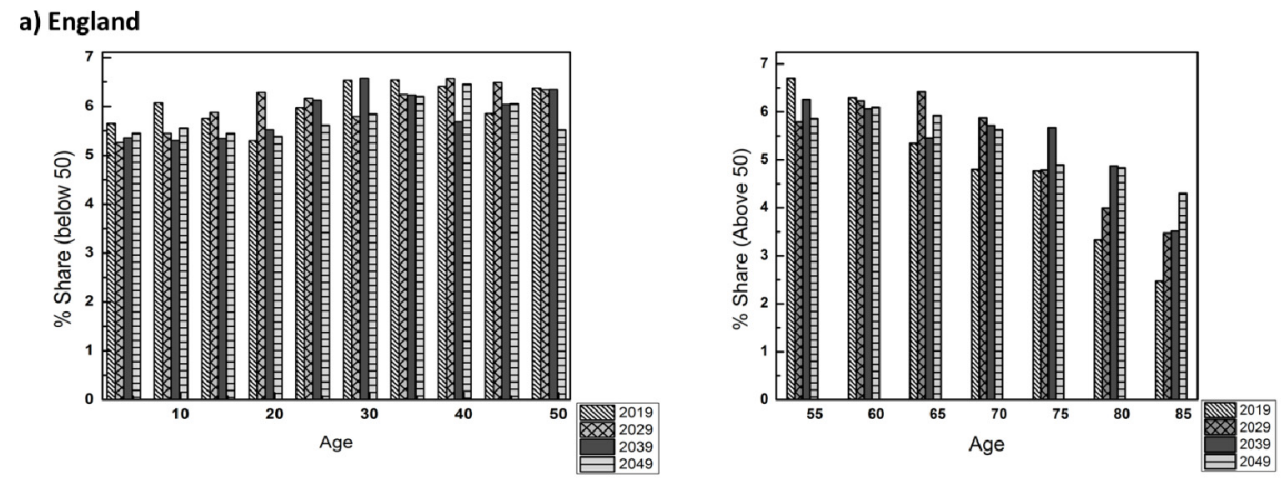

12) https:/www.ons.gov.uk/peoplepopulationandcommunity/populationandmigration/populationprojections/bulletins/nat ionalpopulationprojections/2018based 
Figure 7. Continued
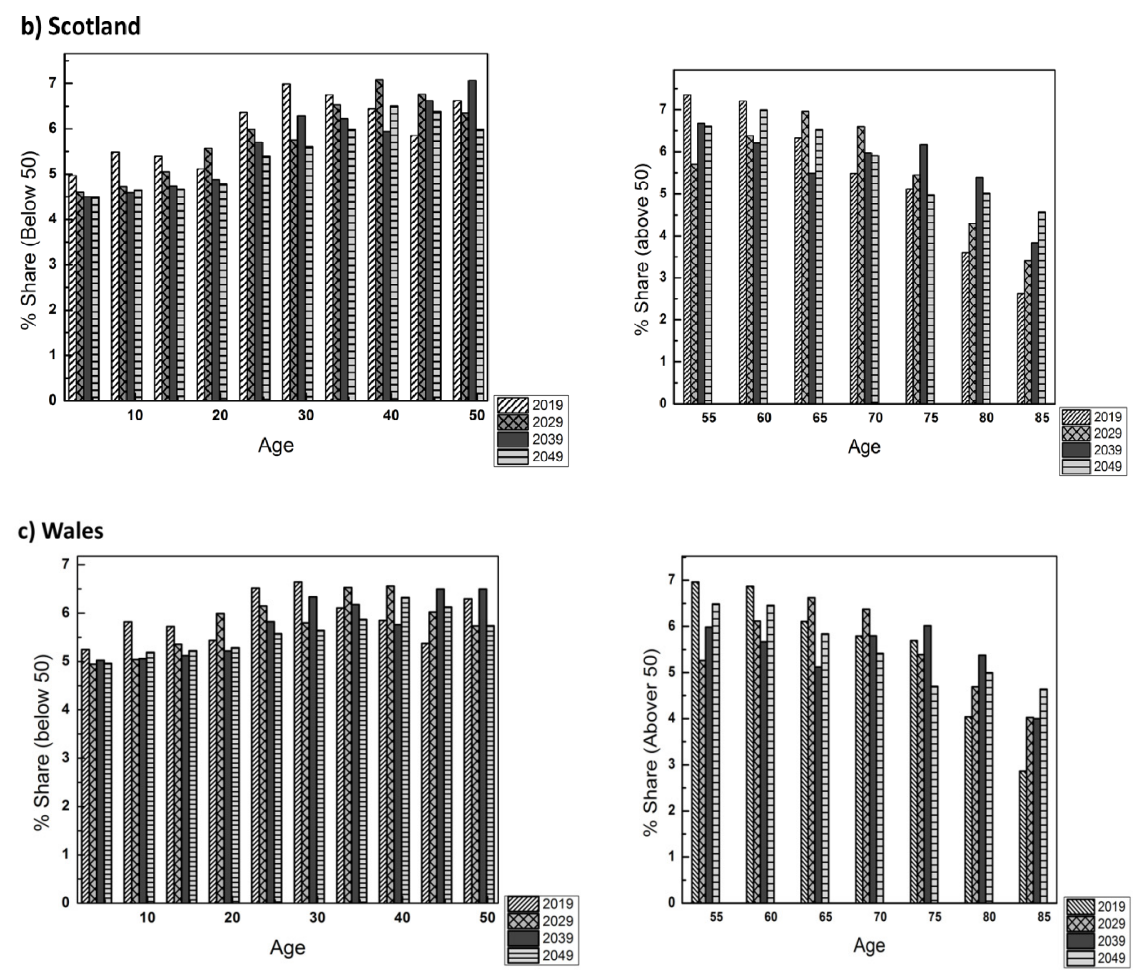

(Source) Authors' calculation based on Office for National Statistics data.

\section{The deeper causes? A look at unemployment and education}

As Table 1 and the analysis in the first part of the study show, unemployment and the state of the economy are important issues that may have impacted the Brexit decision, and education is another important determinant of people's positions regarding Brexit. Hence, we investigate whether concerns about unemployment and education levels can provide some insights into the trends that we have highlighted. In other words, because Crescenzi et al. (2020) demonstrate a relationship between an increase in employment levels and support for the EU, if UK respondents believe that unemployment will last, then their distrust of the EU will remain or increase.

Figures 8a to 8c display the importance of unemployment in survey respondents' considerations. Our data begin in 2003 and end in 2016, but we observe broadly similar patterns nationally (Figure 8a) and across the regions of the UK (Figure 8c). At first, the issue is increasingly considered important over time, possibly related to the financial crisis, but its importance declines after the crisis, and this pattern is exhibited in all regions. As can be expected, more educated respondents are less troubled by the unemployment situation, whereas the respondents that are still studying grow increasingly concerned about unemployment over time. 
Figure 8a. Prevalence of the unemployment issue over time at the national level

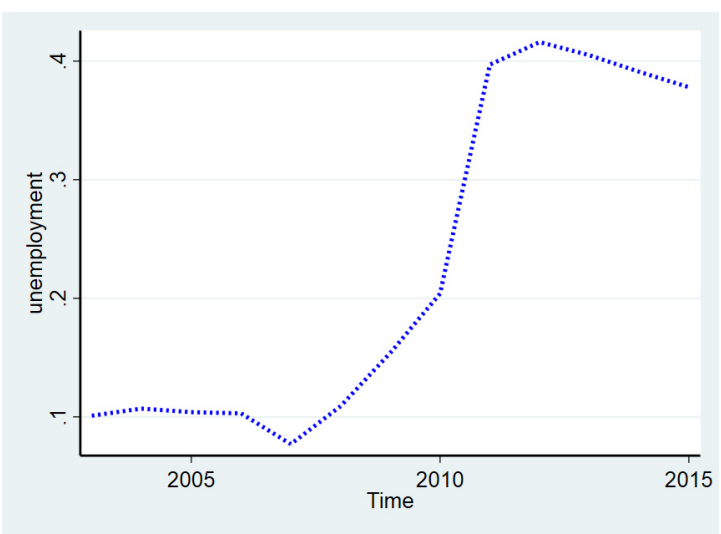

Figure 8b. Prevalence of the unemployment issue over time at the national level by education group

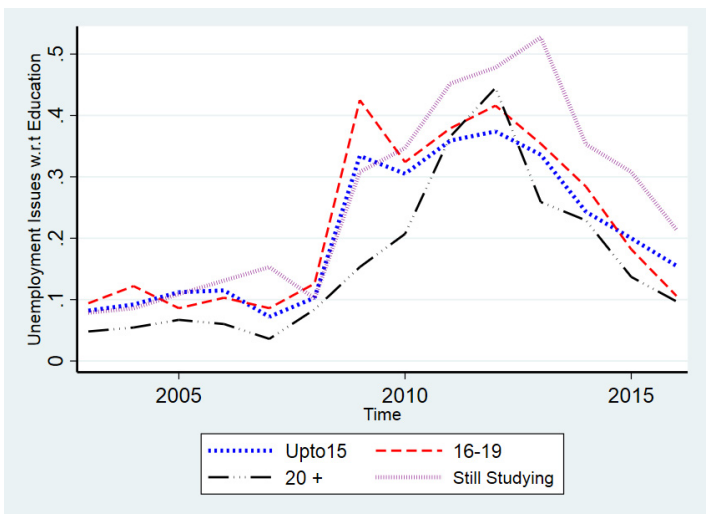

Figure 8c. Prevalence of the unemployment issue over time at the regional level

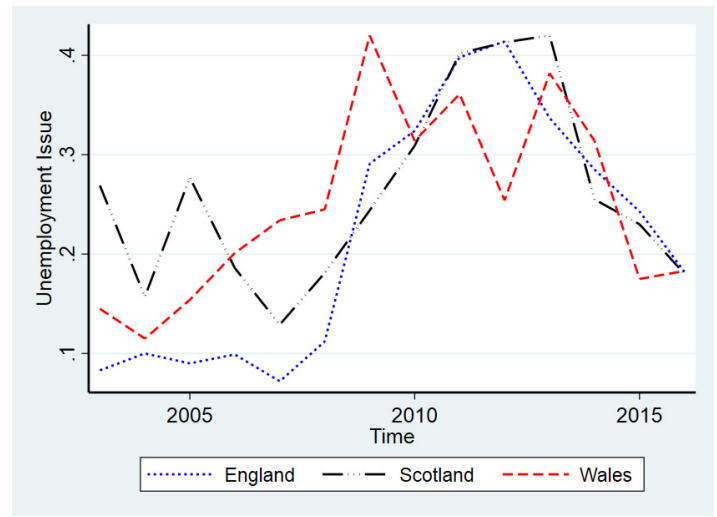


In Figures 9a to 9c, we show the results of an APC analysis of the unemployment issue across cohorts (the numbers of observations by region of residence and education categories make it impossible to analyze the other dimensions of the APC model). The analysis reveals that the importance of the unemployment issue is rising over time, with younger cohorts expressing the most concern about it (see Figure 9a). The regional analysis shows that this pattern is shared across the different regions, although the number of observations does not allow us to analyze the situation for Wales for the last two decades. Interestingly, grouping the observations by level of education does not reveal any divergent trends; respondents at all educational levels and in each birth cohort are feeling more concerned about unemployment.

To summarize, this analysis shows that overall, concerns about unemployment are increasing in the UK for all educational categories. Thus, we can conclude that the level of distrust exhibited by older people cannot be offset by replacing them with future younger cohorts if the unemployment issue remains persistently important for those younger cohorts. Unemployment may play an important role in fueling skeptical attitudes toward the EU in the coming generations, thereby transforming the UK into a structurally Eurosceptic nation. This result is suggestive of the argument made by Nowakowski (2021) regarding the relations among well-being, economic security, and populism.

Figure 9a. Prevalence of the unemployment issue by birth cohort at the national level

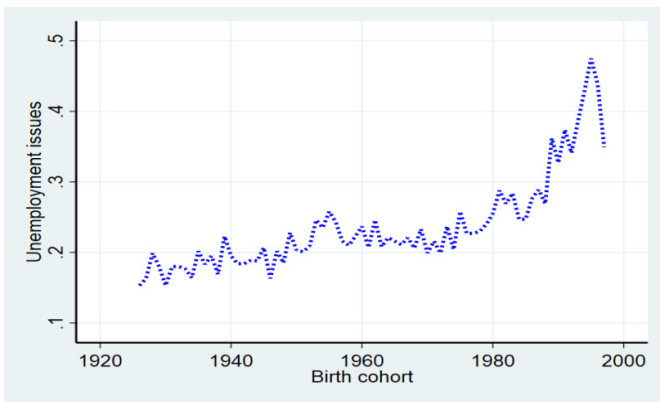

Figure 9b. Prevalence of the unemployment issue by birth cohort at the regional level

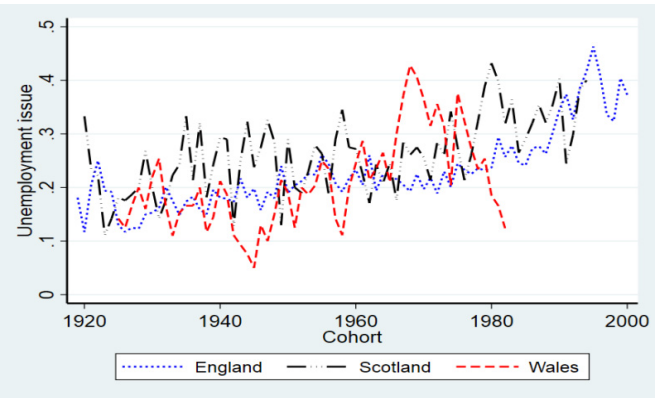

Figure 9c. Prevalence of the unemployment issue by birth cohort at the national level and by education group

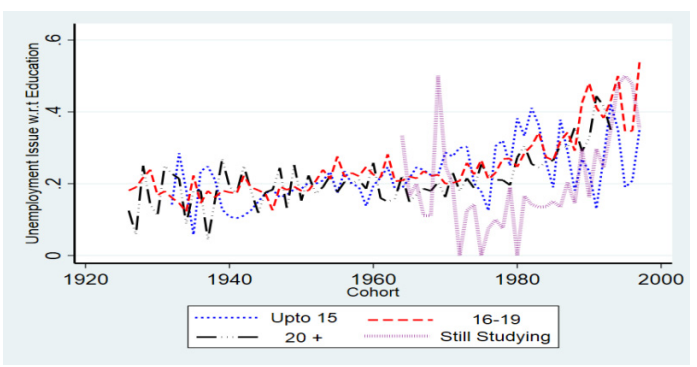

(Source) Authors' calculation based on Eurobarometer data. 


\section{Conclusion}

Returning to the original research questions, this study's analyses tend to suggest that Brexit was inevitable. British people appear to have a deep-rooted level of Euroscepticism that future demographic trends are not likely to reverse. The large turnout ratio on the day of the referendum (72\%, the highest turnout ratio since the 1992 general election) provides some evidence for this claim, as it likely reveals that support for Brexit goes beyond financial and economic reasons and relies on deeply entrenched divisions among voters' values. The distribution of these values is closely related to demographics and, thus, responds to long-running demographic trends.

We therefore analyzed the major determinants of the referendum outcome. Our analysis suggests that the major determinants of distrust toward the EU are also the determinates of Leave votes (i.e., age, education, occupation, and political ideology). Our analysis reveals that these patterns do not change radically over the course of the 20-year span that our dataset on distrust toward the EU covers, nor do they change substantially over the shorter period covered by the British Election Study before and after the Brexit referendum campaign. Moreover, the patterns of determinants of attitudes and preferences do not seem to have changed in the post-Brexit period. Hence, even if some worries about Brexit have arisen following the referendum, it is not that surprising that the margin of people in favor of a Brexit decision has not changed substantially.

Interestingly, our analysis revealed variations in Euroscepticism across different age groups. This finding led us to implement an APC model at the regional and national levels. This analysis revealed that people belonging to older birth cohorts are more distrustful toward the EU and that people become more skeptical of the EU as they age. We therefore find a stark age divide among voters regarding the EU, confirming the findings of Eichengreen et al. (2021). A regional analysis confirms the same trends, although London, Scotland, and Wales differ markedly from the rest of the country and are less Eurosceptic.

We also implemented a population projection analysis that suggests that age effects dominate cohort and period effects: people over age 50 are increasingly comprising a greater share of the UK's population. In 2018, an estimated 1.6 million people were over age 85 and above. This number is expected to nearly double to 3 million by 2049. Low birth rates and a higher life expectancy, which contribute to a rapidly aging population, imply that the current trends will persist over the coming generations. This result suggests that the cohort effect cannot offset the age effect. Thus, ceteris paribus, the UK is and will remain a Eurosceptic nation. 


\section{References}

Alabrese, E., Becker, S. O., Fetzer, T., \& Novy, D. (2019). Who voted for Brexit? Individual and regional data combined. European Journal of Political Economy, 56, 132-150.

Alexandre-Collier, A. (2015). Euroscepticism under Margaret Thatcher and David Cameron: From theory to practice. Observatoire de la Société Britannique, 17, 115-133.

Anderson, C. J., \& Reichert, M. S. (1995). Economic benefits and support for membership in the EU: A cross-national analysis. Journal of Public Policy, 15(3), 231-249.

Arnorsson, A., \& Zoega, G. (2018). On the causes of Brexit. European Journal of Political Economy, 55, 301-323.

Becker, S. O., Fetzer, T., \& Novy, D. (2017). Who voted for Brexit? A comprehensive district-level analysis. Economic Policy, 32(92), 601-650.

Bisciari, P. (2019). A survey of the long-term impact of Brexit on the UK and the EU27 economies (Working Paper No. 366). National Bank of Belgium.

Brigevich, A. (2016). Regional identity and support for Europe: Distinguishing between cultural and political social identity in France. Regional \& Federal Studies, 26(4), 475-507.

Campos, N. F. (2019). B for Brexit: A survey of the economics academic literature. IZA Discussion Papers 12134.

Carey, S. (2002). Undivided loyalties: Is national identity an obstacle to European integration? European Union Politics, 3(4), 387-413.

Clements, B. (2011). Understanding 'utilitarian' support for European integration in Scotland and Wales: The role of economic interests, national identity and party support. Regional \& Federal Studies, 21(1), 1-21.

Clery E., Curtice, J., \& Harding R. (2016). British social attitudes: The 34th Report. London: NatCen Social Research. Retrieved from www.bsa.natcen.ac.uk

Çokluk, Ö. (2010). Logistic regression: Concept and application. Educational Sciences: Theory \& Practice, 10(3), 1397-1407.

Crescenzi, R., Di Cataldo, M., \& Giua, M. (2020). It's not about the money! EU funds, local opportunities, and Euroscepticism. Regional Science and Urban Economics, 84, doi: 10.1016/j.regsciurbeco.2020.103556

Curtice, J. (2017). Why Leave won the UK's EU referendum. JCMS: Journal of Common Market Studies, $55,19-37$.

Danigelis, N. L., \& Cutler, S. J. (1991). An inter-cohort comparison of changes in racial attitudes. Research on Aging, 13(3), 383-404.

Danigelis, N. L, Hardy, M., \& Cutler, S. J. (2007). Population aging, intracohort aging, and sociopolitical attitudes. American Sociological Review, 72(5), 812-830.

David, Q., Pilet, J.-B., \& Van Hamme, G. (2018) Scale matters in contextual analysis of extreme right voting and political attitudes. Kyklos, 71, 509-536.

de Mello, L., Schotte, S., Tiongson, E. R., \& Winkler, H. (2017). Greying the budget: Ageing and preferences over public policies. Kyklos, 70, 70-96.

Eichengreen, B., Mari, R., \& Thwaites, G. (2021). Will Brexit age well? Cohorts, seasoning and the 
age-leave gradient, past, present and future. Economica. doi: https://doi.org/10.1111/ecca.12388 Elgün, Ö., \& Tillman, E. R. (2007). Exposure to European Union policies and support for membership in the candidate countries. Political Research Quarterly, 60(3), 391-400.

Fannon, Z., \& Nielsen, B. (2019). Age-period-cohort models. In Oxford Research Encyclopedia of Economics and Finance (online ed.) Oxford University Press. https://oxfordre.com/economics/view/10.1093/acrefo re/9780190625979.001.0001/acrefore-9780190625979-e-495

Fetzer, T. (2019). Did austerity cause Brexit? American Economic Review, 109(1), 3849-3886.

Fetzer, T., \& Wang, S. (2020). Measuring the regional economic cost of Brexit: Evidence up to 2019. CEPR Discussion Paper, no. 15051.

Fidrmuc, J., Hulényi, M., \& Tunali, Ç. B. (2019). Can money buy EU love? European Journal of Political Economy, 60, Article 101804.

Fullerton, A. S., \& Dixon J. C. (2010). Generational conflict or methodological artifact? Reconsidering the relationship between age and policy attitudes in the U.S., 1984-2008. Public Opinion Quarterly, 74(4), 643-673.

Gabel, M. (1998). Public support for European integration: An empirical test of five theories. The Journal of Politics, 60(2), 333-354.

Gabel, M., \& Palmer, H. D. (1995). Understanding variation in public support for European integration. European Journal of Political Research, 27(1), 3-19.

Garry, J., \& Tilley, J. (2014). Inequality, state ownership and the European Union: How economic context and economic ideology shape support for the European Union. European Union Politics, 16(1), 139-154.

Glenn, N. (1974). Aging and conservatism. The Annals of the American Academy of Political and Social Science, 415, 176-186.

Goodwin, M., \& Milazzo, C. (2017). Taking back control? Investigating the role of immigration in the 2016 vote for Brexit. British Journal of Politics and International Relations, 19(3), 450-464.

Grasso, M., Gray, E., Hay, C., \& Jennings, W. (2017). Thatcher's children, Blair's babies, political socialization and trickle-down value change: An age, period and cohort analysis. British Journal of Political Science, 49, 1-20.

Hall, S. G., \& Henry, B. (2019). The Brexit controversy: What light does evidence shed? Economic Outlook, 43, 5-14.

Haselswerdt, J. (2020). Carving out: Isolating the true effect of self-interest on policy attitudes. American Political Science Review, 114(4), 1103-1116.

Hertner, I., \& Keith, D. (2017). Europhiles or Eurosceptics? Comparing the European policies of the Labour Party and the Liberal Democrats. British Politics, 12(1), 63-89.

Hobolt, S. B. (2016). The Brexit vote: A divided nation, a divided continent. Journal of European Public Policy, 23(9), 1259-1277.

Hooghe, L., \& Marks, G. (2005). Calculation, community and cues: Public opinion on European integration. European Union Politics, 6(4), 419-443.

Jolly, S. K., \& DiGiusto, G. M. (2014). Xenophobia and immigrant contact: French public attitudes towards immigration. The Social Science Journal, 51(3), 464-473. 
Kuhn, T., \& Stoeckel, F. (2014). When European integration becomes costly: The euro crisis and public support for European economic governance. Journal of European Public Policy, 21(4), 624-641.

Latorre, M. C., Olekseyuk Z., Yonezawa H., \& Robinson S. (2019). Brexit: Everyone loses, but Britain loses the most (Working Paper Series WP19-5). Peterson Institute for International Economics.

Lee, N., Morris, K., \& Kemeny, T. (2018). Immobility and the Brexit vote. Cambridge Journal of Regions, Economy and Society, 11(1), 143-163.

Liberini, F., Proto, E., Oswald, A. J., \& Redoano, M. (2019). Was Brexit caused by the old and unhappy? Or by financial feelings? Journal of Economic Behavior \& Organization, 161, 287-302.

Los, B., McCann, P., Springford, J., \& Thissen, M. (2017). The mismatch between local voting and the local economic consequences of Brexit. Regional Studies, 51(5), 786-799.

Luedtke, A. (2005). European integration, public opinion and immigration policy: Testing the impact of national identity. European Union Politics, 6(1), 83-112.

McLaren, L. (2007). Explaining mass-level Euroscepticism: Identity, interests, and institutional distrust. Acta Politica, 42(2-3), 233-251.

Menon, A., Surridge, P., Duffy, B., Katwala, S., \& Ford, R. (2019). Brexit and public opinion 2019. London: The UK in a Changing Europe.

Nowakowski, A. (2021). Do unhappy citizens vote for populism? European Journal of Political Economy, 68. doi: 10.1016/j.ejpoleco.2020.101985

O'Reilly, J., Froud, J., Johal, S., Williams, K., \& Warhurst, C. (2016). Brexit: Understanding the socioeconomic origins and consequences. Socio-Economic Review, 14(4), 807-854.

Peterson, J. C., Smith, K. B., \& Hibbing, J. R. (2020), Do people really become more conservative as they age? The Journal of Politics, 82(2), 600-611.

Powdthavee, N., Plagnol, A. C., Frijters, P., \& Clark, A. E. (2019). Who got the Brexit blues? The effect of Brexit on subjective wellbeing in the UK. Economica, 86, 471-494.

Rhodebeck, L. A. (1993). The politics of greed? Political preferences among the elderly. The Journal of Politics, 55(2), 342-364.

Schonfeld, B., \& Winter-Levy, S. (2019). Policy or partisanship in the United Kingdom? Quasi-experimental evidence from Brexit. The Journal of Politics. doi: 10.1086/712143

Schwadel, P., \& Garneau, C. R. H. (2014). An age-period-cohort analysis of political tolerance in the United States. The Sociological Quarterly, 55(2), 421-452.

Sørensen, R. (2013). Does ageing affect preferences for welfare spending? A study of peoples' spending preferences in 22 countries, 1985-2006. European Journal of Political Economy, 29, 259-271.

Tilley, J., \& Evans, G. (2014). Ageing and generational effects on vote choice: Combining cross-sectional and panel data to estimate APC effects. Electoral Studies, 33, 19-27. 


\section{Appendix}

\section{A. Data collection}

We use all of the waves of the Eurobarometer Survey that include a question about trust in the EU (i.e., from wave 48.0 in November 1997 to wave 91.5 in July 2019). Table A1 provides details on the data collected by Eurobarometer.

To compare data on distrust from the Eurobarometer survey and data on Leave votes from the British Election Study and to check the evolution of Leave votes, we use wave 7 (conducted in May 2016), wave 8 (conducted in June 2016), wave 13 (conducted in June 2018), and wave 15 (conducted in March 2019) from the British Election Study. Table A2 shows details of the data collected by the British Election Study.

Table A1. Data Collection by Eurobarometer Each Year from 1997 to 2018

\begin{tabular}{|c|c|c|c|c|c|}
\hline Sample Number & Name & Code & Period & Year & Wave Number in Year \\
\hline 1 & 48.0 & 2959 & Oct-Nov & 1997 & $1^{\text {st }}$ \\
\hline 2 & 50.1 & 3086 & Nov-Dec & 1998 & $1^{\text {st }}$ \\
\hline 3 & 51.0 & 3171 & Mar-Apr & 1999 & $1^{\mathrm{st}}$ \\
\hline 4 & 55.1 & 3507 & Apr-May & 2001 & $1^{\text {st }}$ \\
\hline 5 & 56.2 & 3627 & Oct-Nov & 2001 & $2^{\text {nd }}$ \\
\hline 6 & 57.1 & 3639 & Mar-Apr & 2002 & $1^{\text {st }}$ \\
\hline 7 & 59.1 & 3904 & Mar-Apr & 2003 & $1^{\text {st }}$ \\
\hline 8 & 60.1 & 3938 & Oct-Nov & 2003 & $2^{\text {nd }}$ \\
\hline 9 & 61.0 & 4056 & Feb-Mar & 2004 & $1^{\mathrm{st}}$ \\
\hline 10 & 62.0 & 4229 & Oct-Nov & 2004 & $2^{\text {nd }}$ \\
\hline 11 & 63.4 & 4411 & May-June & 2005 & $1^{\mathrm{st}}$ \\
\hline 12 & 65.2 & 4506 & Mar-Apr & 2006 & $1^{\mathrm{st}}$ \\
\hline 13 & 66.1 & 4526 & Sep-Oct & 2006 & $2^{\text {nd }}$ \\
\hline 14 & 67.2 & 4530 & Apr-May & 2007 & $1^{\mathrm{st}}$ \\
\hline 15 & 68.1 & 4565 & Sep-Nov & 2007 & $2^{\text {nd }}$ \\
\hline 16 & 69.2 & 4744 & Mar-Apr & 2008 & $1^{\mathrm{st}}$ \\
\hline 17 & 70.1 & 4819 & Oct-Nov & 2008 & $2^{\text {nd }}$ \\
\hline 18 & 71.1 & 4971 & Jan-Feb & 2009 & $1^{\mathrm{st}}$ \\
\hline 19 & 71.3 & 4973 & June-July & 2009 & $2^{\text {nd }}$ \\
\hline 20 & 72.4 & 4994 & Oct-Nov & 2009 & $3^{\text {rd }}$ \\
\hline 21 & 73.4 & 5234 & Apr-May & 2010 & $1^{\mathrm{st}}$ \\
\hline 22 & 74.2 & 5449 & Nov-Dec & 2010 & $2^{\text {nd }}$ \\
\hline 23 & 75.3 & 5481 & Apr-May & 2011 & $1^{\mathrm{st}}$ \\
\hline 24 & 76.3 & 5567 & Nov-Dec & 2011 & $2^{\text {nd }}$ \\
\hline 25 & 77.3 & 5612 & Apr-May & 2012 & $1^{\text {st }}$ \\
\hline 26 & 78.1 & 5685 & Nov-Dec & 2012 & $2^{\text {nd }}$ \\
\hline
\end{tabular}


Table A1. Continued

\begin{tabular}{cccccc}
\hline Sample Number & Name & Code & Period & Year & Wave Number in Year \\
\hline 27 & 79.3 & 5689 & Apr-May & 2013 & $1^{\text {st }}$ \\
28 & 80.1 & 5876 & Nov-Dec & 2013 & $2^{\text {nd }}$ \\
29 & 81.2 & 5913 & Mar-Apr & 2014 & $1^{\text {st }}$ \\
30 & 81.4 & 5928 & May-June & 2014 & $2^{\text {nd }}$ \\
31 & 82.3 & 5932 & Nov-Dec & 2014 & $3^{\text {rd }}$ \\
32 & 83.1 & 5964 & Feb-Mar & 2015 & $1^{\text {st }}$ \\
33 & 83.3 & 5998 & Apr-May & 2015 & $2^{\text {nd }}$ \\
34 & 84.3 & 6643 & Nov-Dec & 2015 & $3^{\text {rd }}$ \\
35 & 85.2 & 6694 & May-June & 2016 & $1^{\text {st }}$ \\
36 & 86.2 & 6788 & Nov-Dec & 2016 & $2^{\text {nd }}$ \\
37 & 87.3 & 6863 & May-June & 2017 & $1^{\text {st }}$ \\
38 & 88.3 & 6928 & Nov-Dec & 2017 & $2^{\text {nd }}$ \\
39 & 89.1 & 6963 & Mar-Apr & 2018 & $1^{\text {st }}$ \\
40 & 91.5 & 7576 & June-July & 2019 & $1^{\text {st }}$ \\
\hline
\end{tabular}

(Source) Authors' calculation based on the Eurobarometer survey.

Table A2. Data Coverage by the British Election Study

\begin{tabular}{ccccc}
\hline Sample Number & Wave Number & Time Period & Year & Wave Number in Year \\
\hline 1 & $7^{\text {th }}$ & Apr & 2016 & $1^{\text {st }}$ \\
2 & $8^{\text {th }}$ & June & 2016 & $2^{\text {nd }}$ \\
3 & $13^{\text {th }}$ & June & 2017 & $1^{\text {st }}$ \\
4 & $15^{\text {th }}$ & March & 2019 & $1^{\text {st }}$ \\
\hline
\end{tabular}

(Source) Authors' calculation based on the British Election Study.

\section{B. APC analysis: Tables}

Table B1. Mean Distrust over Time with Respect to Birth Cohort

\begin{tabular}{cccccccccccc}
\hline \multirow{2}{*}{ Survey } & \multicolumn{2}{c}{$\mathbf{1 9 2 6 - 1 9 2 9}$} & \multicolumn{2}{c}{$\mathbf{1 9 3 0}-\mathbf{1 9 3 3}$} & \multicolumn{2}{c}{$\mathbf{1 9 3 4 - 1 9 3 7}$} & \multicolumn{2}{c}{$\mathbf{1 9 3 8 - 1 9 4 1}$} & \multicolumn{2}{c}{$\mathbf{1 9 4 2 - 1 9 4 5}$} \\
\cline { 2 - 11 } & $\begin{array}{c}\text { Mean } \\
\text { Distrust }\end{array}$ & Variance & $\begin{array}{c}\text { Mean } \\
\text { Distrust }\end{array}$ & Variance & $\begin{array}{c}\text { Mean } \\
\text { Distrust }\end{array}$ & Variance & $\begin{array}{c}\text { Mean } \\
\text { Distrust }\end{array}$ & Variance & $\begin{array}{c}\text { Mean } \\
\text { Distrust }\end{array}$ & Variance \\
\hline 1997 & 0.727 & 0.204 & 0.75 & 0.191 & 0.725 & 0.204 & 0.611 & 0.242 & 0.625 & 0.240 \\
1998 & 0.685 & 0.221 & 0.681 & 0.221 & 0.622 & 0.240 & 0.622 & 0.239 & 0.604 & 0.244 \\
1999 & 0.730 & 0.204 & 0.742 & 0.196 & 0.812 & 0.156 & 0.702 & 0.214 & 0.777 & 0.176 \\
2001 & 0.672 & 0.223 & 0.614 & 0.239 & 0.711 & 0.207 & 0.688 & 0.217 & 0.684 & 0.217 \\
2002 & 0.85 & 0.133 & 0.70 & 0.219 & 0.688 & 0.219 & 0.666 & 0.228 & 0.712 & 0.207 \\
2003 & 0.86 & 0.122 & 0.819 & 0.148 & 0.765 & 0.181 & 0.887 & 0.101 & 0.817 & 0.150 \\
2004 & 0.66 & 0.228 & 0.761 & 0.184 & 0.787 & 0.168 & 0.75 & 0.190 & 0.768 & 0.179 \\
2005 & 0.882 & 0.106 & 0.833 & 0.142 & 0.789 & 0.156 & 0.839 & 0.136 & 0.764 & 0.183 \\
2006 & 0.776 & 0.175 & 0.875 & 0.110 & 0.807 & 0.183 & 0.858 & 0.122 & 0.789 & 0.167 \\
2007 & 0.625 & 0.236 & 0.752 & 0.187 & 0.75 & 0.188 & 0.790 & 0.166 & 0.717 & 0.204 \\
\hline
\end{tabular}


Table B1. Continued

\begin{tabular}{|c|c|c|c|c|c|c|c|c|c|c|}
\hline \multirow[b]{2}{*}{ Survey } & \multicolumn{2}{|c|}{$1926-1929$} & \multicolumn{2}{|c|}{ 1930-1933 } & \multicolumn{2}{|c|}{ 1934-1937 } & \multicolumn{2}{|c|}{$1938-1941$} & \multicolumn{2}{|c|}{ 1942-1945 } \\
\hline & $\begin{array}{c}\text { Mean } \\
\text { Distrust }\end{array}$ & Variance & $\begin{array}{c}\text { Mean } \\
\text { Distrust }\end{array}$ & Variance & $\begin{array}{c}\text { Mean } \\
\text { Distrust }\end{array}$ & Variance & $\begin{array}{c}\text { Mean } \\
\text { Distrust }\end{array}$ & Variance & $\begin{array}{c}\text { Mean } \\
\text { Distrust }\end{array}$ & Variance \\
\hline 2008 & 0.774 & 0.177 & 0.725 & 0.200 & 0.754 & 0.186 & 0.858 & 0.122 & 0.769 & 0.178 \\
\hline 2009 & 0.829 & 0.142 & 0.789 & 0.167 & 0.805 & 0.157 & 0.857 & 0.122 & 0.840 & 0.134 \\
\hline 2010 & 0.843 & 0.134 & 0.857 & 0.123 & 0.795 & 0.164 & 0.905 & 0.086 & 0.837 & 0.136 \\
\hline 2011 & 0.795 & 0.165 & 0.931 & 0.064 & 0.871 & 0.112 & 0.812 & 0.153 & 0.902 & 0.088 \\
\hline 2012 & 0.744 & 0.194 & 0.805 & 0.158 & 0.931 & 0.064 & 0.915 & 0.078 & 0.950 & 0.047 \\
\hline 2013 & 0.804 & 0.160 & 0.82 & 0.150 & 0.891 & 0.096 & 0.885 & 0.102 & 0.884 & 0.103 \\
\hline 2014 & 0.791 & 0.168 & 0.781 & 0.172 & 0.798 & 0.161 & 0.829 & 0.142 & 0.853 & 0.125 \\
\hline 2015 & 0.645 & 0.233 & 0.77 & 0.178 & 0.805 & 0.157 & 0.846 & 0.130 & 0.797 & 0.161 \\
\hline 2016 & 0.705 & 0.219 & 0.607 & 0.247 & 0.804 & 0.160 & 0.761 & 0.185 & 0.888 & 0.099 \\
\hline Total & 0.755 & 0.184 & 0.781 & 0.170 & 0.792 & 0.164 & 0.820 & 0.146 & 0.809 & 0.153 \\
\hline Frequency & \multicolumn{2}{|c|}{929} & \multicolumn{2}{|c|}{1399} & \multicolumn{2}{|c|}{1647} & \multicolumn{2}{|c|}{1692} & \multicolumn{2}{|c|}{1978} \\
\hline
\end{tabular}

Table B2. Mean Distrust over Time with Respect to Birth Cohort

\begin{tabular}{|c|c|c|c|c|c|c|c|c|}
\hline \multirow{2}{*}{ Time Period } & \multicolumn{2}{|c|}{ 1946-1949 } & \multicolumn{2}{|c|}{$1950-1953$} & \multicolumn{2}{|c|}{ 1954-1957 } & \multicolumn{2}{|c|}{$1958-1961$} \\
\hline & Mean Distrust & Variance & Mean Distrust & Variance & Mean Distrust & Variance & Mean Distrust & Variance \\
\hline 1997 & 0.702 & 0.213 & 0.596 & 0.244 & 0.613 & 0.242 & 0.656 & 0.228 \\
\hline 1998 & 0.6 & 0.245 & 0.672 & 0.223 & 0.634 & 0.236 & 0.542 & 0.251 \\
\hline 1999 & 0.8 & 0.164 & 0.589 & 0.248 & 0.641 & 0.232 & 0.741 & 0.194 \\
\hline 2001 & 0.724 & 0.201 & 0.659 & 0.226 & 0.629 & 0.235 & 0.731 & 0.199 \\
\hline 2002 & 0.641 & 0.235 & 0.756 & 0.188 & 0.529 & 0.256 & 0.709 & 0.209 \\
\hline 2003 & 0.783 & 0.171 & 0.733 & 0.197 & 0.743 & 0.192 & 0.792 & 0.165 \\
\hline 2004 & 0.757 & 0.184 & 0.762 & 0.182 & 0.627 & 0.236 & 0.734 & 0.196 \\
\hline 2005 & 0.823 & 0.148 & 0.767 & 0.182 & 0.76 & 0.185 & 0.717 & 0.207 \\
\hline 2006 & 0.757 & 0.184 & 0.75 & 0.189 & 0.689 & 0.216 & 0.739 & 0.194 \\
\hline 2007 & 0.769 & 0.178 & 0.725 & 0.200 & 0.677 & 0.219 & 0.619 & 0.236 \\
\hline 2008 & 0.838 & 0.136 & 0.729 & 0.198 & 0.712 & 0.206 & 0.755 & 0.186 \\
\hline 2009 & 0.807 & 0.156 & 0.834 & 0.138 & 0.796 & 0.163 & 0.763 & 0.181 \\
\hline 2010 & 0.838 & 0.136 & 0.867 & 0.115 & 0.825 & 0.145 & 0.8 & 0.161 \\
\hline 2011 & 0.840 & 0.134 & 0.841 & 0.134 & 0.86 & 0.121 & 0.798 & 0.162 \\
\hline 2012 & 0.911 & 0.081 & 0.820 & 0.147 & 0.845 & 0.131 & 0.852 & 0.126 \\
\hline 2013 & 0.848 & 0.128 & 0.852 & 0.126 & 0.9 & 0.090 & 0.765 & 0.180 \\
\hline 2014 & 0.846 & 0.130 & 0.902 & 0.088 & 0.875 & 0.108 & 0.828 & 0.142 \\
\hline 2015 & 0.777 & 0.173 & 0.761 & 0.182 & 0.834 & 0.138 & 0.778 & 0.173 \\
\hline 2016 & 0.840 & 0.135 & 0.816 & 0.152 & 0.75 & 0.189 & 0.808 & 0.157 \\
\hline Total & 0.803 & 0.157 & 0.782 & 0.169 & 0.759 & 0.184 & 0.753 & 0.185 \\
\hline Frequency & 2112 & & 181 & & & 1731 & 1775 & \\
\hline
\end{tabular}


Table B3. Mean Distrust over Time with Respect to Birth Cohort

\begin{tabular}{|c|c|c|c|c|c|c|c|c|c|c|}
\hline \multirow[b]{2}{*}{ Survey } & \multicolumn{2}{|c|}{ 1962-1965 } & \multicolumn{2}{|c|}{ 1966-1969 } & \multicolumn{2}{|c|}{ 1970-1973 } & \multicolumn{2}{|c|}{ 1974-1977 } & \multicolumn{2}{|c|}{ 1978-1981 } \\
\hline & $\begin{array}{c}\text { Mean } \\
\text { Distrust }\end{array}$ & Variance & $\begin{array}{c}\text { Mean } \\
\text { Distrust }\end{array}$ & Variance & $\begin{array}{c}\text { Mean } \\
\text { Distrust }\end{array}$ & Variance & $\begin{array}{c}\text { Mean } \\
\text { Distrust }\end{array}$ & Variance & $\begin{array}{c}\text { Mean } \\
\text { Distrust }\end{array}$ & Variance \\
\hline 1997 & 0.75 & 0.190 & 0.653 & 0.230 & 0.6 & 0.244 & 0.6 & 0.245 & 0.446 & 0.251 \\
\hline 1998 & 0.597 & 0.243 & 0.552 & 0.25 & 0.709 & 0.209 & 0.474 & 0.253 & 0.541 & 0.253 \\
\hline 1999 & 0.698 & 0.213 & 0.649 & 0.231 & 0.818 & 0.152 & 0.6 & 0.245 & 0.636 & 0.236 \\
\hline 2001 & 0.674 & 0.220 & 0.604 & 0.240 & 0.572 & 0.246 & 0.631 & 0.235 & 0.623 & 0.236 \\
\hline 2002 & 0.685 & 0.218 & 0.661 & 0.227 & 0.625 & 0.238 & 0.553 & 0.252 & 0.5 & 0.254 \\
\hline 2003 & 0.689 & 0.216 & 0.634 & 0.233 & 0.716 & 0.204 & 0.582 & 0.245 & 0.539 & 0.251 \\
\hline 2004 & 0.621 & 0.236 & 0.681 & 0.219 & 0.651 & 0.228 & 0.529 & 0.252 & 0.517 & 0.252 \\
\hline 2005 & 0.631 & 0.236 & 0.571 & 0.248 & 0.5 & 0.254 & 0.607 & 0.243 & 0.384 & 0.491 \\
\hline 2006 & 0.663 & 0.224 & 0.616 & 0.238 & 0.471 & 0.252 & 0.495 & 0.252 & 0.578 & 0.247 \\
\hline 2007 & 0.581 & 0.245 & 0.616 & 0.238 & 0.631 & 0.234 & 0.546 & 0.251 & 0.512 & 0.253 \\
\hline 2008 & 0.758 & 0.184 & 0.698 & 0.212 & 0.592 & 0.243 & 0.592 & 0.244 & 0.611 & 0.240 \\
\hline 2009 & 0.748 & 0.189 & 0.732 & 0.197 & 0.725 & 0.199 & 0.634 & 0.233 & 0.666 & 0.223 \\
\hline 2010 & 0.684 & 0.218 & 0.777 & 0.173 & 0.736 & 0.196 & 0.732 & 0.197 & 0.741 & 0.192 \\
\hline 2011 & 0.834 & 0.139 & 0.821 & 0.148 & 0.772 & 0.177 & 0.741 & 0.193 & 0.693 & 0.214 \\
\hline 2012 & 0.780 & 0.172 & 0.787 & 0.168 & 0.826 & 0.144 & 0.815 & 0.152 & 0.836 & 0.371 \\
\hline 2013 & 0.810 & 0.154 & 0.843 & 0.132 & 0.760 & 0.183 & 0.768 & 0.179 & 0.649 & 0.229 \\
\hline 2014 & 0.765 & 0.180 & 0.827 & 0.143 & 0.776 & 0.173 & 0.738 & 0.193 & 0.651 & 0.228 \\
\hline 2015 & 0.696 & 0.212 & 0.735 & 0.195 & 0.694 & 0.212 & 0.677 & 0.219 & 0.627 & 0.235 \\
\hline 2016 & 0.730 & 0.199 & 0.632 & 0.235 & 0.688 & 0.217 & 0.605 & 0.245 & 0.487 & 0.256 \\
\hline Total & 0.707 & 0.206 & 0.697 & 0.210 & 0.682 & 0.216 & 0.643 & 0.229 & 0.614 & 0.236 \\
\hline Frequency & \multicolumn{2}{|c|}{1936} & \multicolumn{2}{|c|}{1944} & \multicolumn{2}{|c|}{1815} & \multicolumn{2}{|c|}{1627} & \multicolumn{2}{|c|}{1626} \\
\hline
\end{tabular}


Table B4. Mean Distrust over Time with Respect to Birth Cohort

\begin{tabular}{|c|c|c|c|c|c|c|c|c|c|c|}
\hline \multirow[b]{2}{*}{ Survey } & \multicolumn{2}{|c|}{ 1982-1985 } & \multicolumn{2}{|c|}{ 1986-1989 } & \multicolumn{2}{|c|}{ 1990-1993 } & \multicolumn{2}{|c|}{ 1994-1997 } & \multicolumn{2}{|c|}{ 1998-2000 } \\
\hline & $\begin{array}{c}\text { Mean } \\
\text { Distrust }\end{array}$ & Variance & $\begin{array}{c}\text { Mean } \\
\text { Distrust }\end{array}$ & Variance & $\begin{array}{c}\text { Mean } \\
\text { Distrust }\end{array}$ & Variance & $\begin{array}{c}\text { Mean } \\
\text { Distrust }\end{array}$ & Variance & $\begin{array}{c}\text { Mean } \\
\text { Distrust }\end{array}$ & Variance \\
\hline 1997 & 0.2 & 0.177 & & & & & & & & \\
\hline 1998 & 0.26 & 0.204 & & & & & & & & \\
\hline 1999 & 0.523 & 0.255 & & & & & & & & \\
\hline 2001 & 0.526 & 0.252 & 0.470 & 0.264 & & & & & & \\
\hline 2002 & 0.522 & 0.253 & 0.666 & 0.25 & & & & & & \\
\hline 2003 & 0.533 & 0.25 & 0.535 & 0.253 & & & & & & \\
\hline 2004 & 0.481 & 0.252 & 0.35 & 0.229 & & & & & & \\
\hline 2005 & 0.540 & 0.255 & 0.32 & 0.225 & & & & & & \\
\hline 2006 & 0.602 & 0.242 & 0.436 & 0.249 & 0.170 & 0.144 & & & & \\
\hline 2007 & 0.493 & 0.253 & 0.455 & 0.251 & 0.396 & 0.243 & & & & \\
\hline 2008 & 0.530 & 0.252 & 0.586 & 0.245 & 0.338 & 0.226 & & & & \\
\hline 2009 & 0.638 & 0.232 & 0.513 & 0.252 & 0.415 & 0.245 & 0.5 & 0.266 & & \\
\hline 2010 & 0.719 & 0.204 & 0.684 & 0.217 & 0.594 & 0.244 & 0.370 & 0.242 & & \\
\hline 2011 & 0.75 & 0.189 & 0.637 & 0.233 & 0.554 & 0.249 & 0.5 & 0.254 & & \\
\hline 2012 & 0.710 & 0.207 & 0.716 & 0.204 & 0.746 & 0.190 & 0.535 & 0.252 & & \\
\hline 2013 & 0.754 & 0.186 & 0.704 & 0.210 & 0.690 & 0.216 & 0.604 & 0.241 & 0.428 & 0.285 \\
\hline 2014 & 0.688 & 0.215 & 0.639 & 0.232 & 0.609 & 0.239 & 0.568 & 0.247 & 0.277 & 0.206 \\
\hline 2015 & 0.627 & 0.235 & 0.683 & 0.218 & 0.557 & 0.248 & 0.504 & 0.252 & 0.28 & 0.205 \\
\hline 2016 & 0.622 & 0.239 & 0.627 & 0.238 & 0.657 & 0.230 & 0.459 & 0.255 & 0.333 & 0.231 \\
\hline Total & 0.610 & 0.237 & 0.584 & 0.243 & 0.538 & 0.248 & 0.528 & 0.249 & 0.299 & 0.210 \\
\hline Frequency & \multicolumn{2}{|c|}{1572} & \multicolumn{2}{|c|}{1234} & \multicolumn{2}{|c|}{920} & \multicolumn{2}{|c|}{494} & \multicolumn{2}{|c|}{117} \\
\hline
\end{tabular}

